\title{
The Original Public Meaning of Amendment in the Origination Clause Versus the Patient Protection and Affordable Care Act
}

\author{
Daniel J. Smyth* \\ Independent Researcher
}

\begin{abstract}
Robert Natelson recently published his article, The Founders' Origination Clause and Implications for the Affordable Care Act, in the Harvard Journal of Law \& Public Policy. This article argued the original understanding of the scope of the Senate's power to amend the House of Representatives' bills for raising revenue in the Origination Clause permits complete substitutes that are new bills for raising revenue, such as the Patient Protection and Affordable Care Act (PPACA). The original understanding of a constitutional word or provision is what the ratifiers of the Constitution thought was the meaning of the word or provision. When the Senate originated PPACA as an amendment to the House's Service Members Home Ownership Tax Act of 2009, the Senate replaced the entire House bill, except for the bill's number, with PPACA.

I consider the original public meaning — not the original understanding - of a constitutional word or provision, unless unrecoverable, to be the controlling meaning of that word or provision. The original public meaning is the meaning that a "reasonable speaker of English" during the founding era would have ascribed to the word or provision. My article argues the original public meaning of amendment is clear and disallows complete substitutes. For instance, founding-era dictionaries indicate an amendment was a change or alteration to something that transformed the thing from bad to better. This definition suggests an amendment must not be a complete substitute because an amendment must preserve at least a part of the thing being amended so that there is something to transform from bad to better.

My article further argues the preponderance of evidence suggests the original understanding of the scope of an amendment actually disallows complete substitutes. For example, much evidence from the Philadelphia Convention, Confederation Congress, state legislatures, and state conventions suggests the dominant view among the founders was that an amendment to the Articles of Confederation, the legal compact between 13 states enacted in 1781, could not be a complete substitute.

My conclusion argues PPACA or any other such complete substitute violates the original public meaning of the scope of an amendment.
\end{abstract}

* Daniel J. Smyth earned his Master of Public Policy from the University of Maryland, Baltimore County. He is an independent researcher and the cofounder of LibertyBlog.org. He thanks the following people for reviewing his article: Marion and Michael P. Smyth; Nicholas Schmitz, M. Phil. (Oxford); Andrew Hyman, Esq.; Michael D. Ramsey, Hugh and Hazel Darling Foundation Professor of Law, University of San Diego School of Law; Michael W. McConnell, Richard and Frances Mallery Professor of Law, Stanford Law School; Gary S. Lawson, Philip S. Beck Professor of Law, Boston University School of Law; Ronald Krotoszynski, John S. Stone Chairholder of Law, University of Alabama School of Law; Anne Richardson Oakes, Reader in American Legal Studies, Birmingham City University School of Law; and his anonymous reviewers at the British Journal of American Legal Studies. Daniel is responsible for any errors in this article. 


\section{CONTENTS}

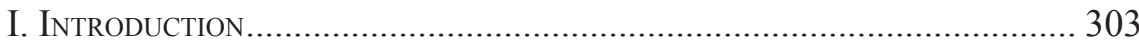

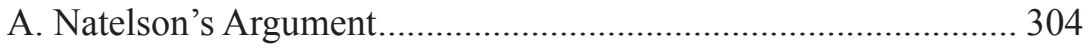

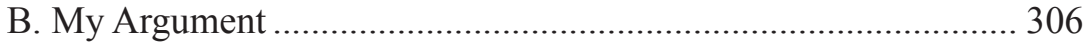

II. The Original Public Meaning of Amendment ..................................... 309

A. Dictionary Definitions of Amendment......................................... 309

B. Articles, Pamphlets, Letters, and Other Writings............................311

1. Amendments Could Not Be Complete Substitutes.....................311

2. Amendments Had to Preserve Something ................................. 317

3. Amendments Could Be Extensive .............................................. 319

4. Amendments Could Be Complete Substitutes......................... 320

C. Summary of the Original Public Meaning of Amendment ......... 322

III. The Original Understanding Of The Scope Of An Amendment..... 324

A. British Parliament ...................................................................... 324

1. Amendments Could Not Be Complete Substitutes................... 325

2. Amendments Could Be Extensive .......................................... 326

3. Summary of British Parliament ............................................... 327

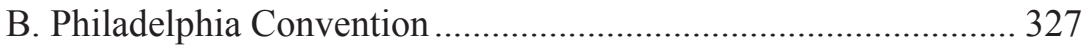

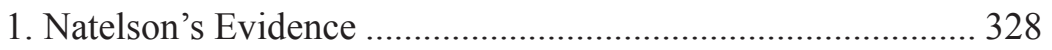

2. My Evidence............................................................................. 329

3. Summary of the Philadelphia Convention................................. 333

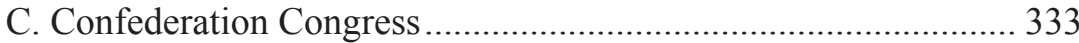

1. Amendments Could Not Be Complete Substitutes................... 333

2. Summary of the Confederation Congress................................... 334

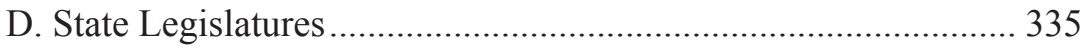

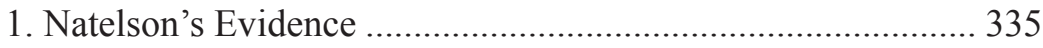

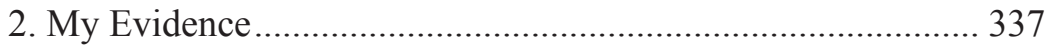

3. Summary of the State Legislatures ............................................ 340 


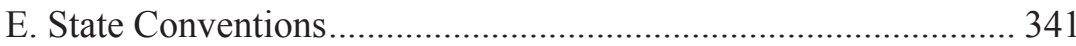

1. Natelson's Evidence ………………………………….......... 341

2. My Evidence....................................................................... 342

3. Summary of the State Conventions ........................................... 350

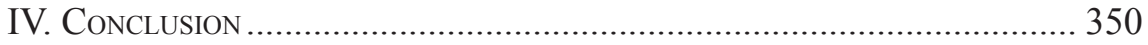

Appendix: Additional Ratification Records That Suggest Amendments

Could Not Be Complete Substitutes ................................................ 352

As far as I can learn, the express purpose of the [Philadelphia] $[\mathrm{C}]$ onvention was, to revise and amend, the [A]rticles [of Confederation].... Instead of this.... they built a stately palace [new constitution] after their own fancies.... Had they preserved only one article of the union [the Articles], and built the present [new] constitution to it, the objection of innovation would be unreasonable[.]

- Denatus, Virginia Independent Chronicle, June 11, 1788

\section{INTRODUCTION}

Robert Natelson's recent article, The Founders' Origination Clause and Implications for the Affordable Care Act,${ }^{1}$ is the largest study to date of the original understanding of the Constitution's Origination Clause. The original understanding of a constitutional word or provision is what the ratifiers of the Constitution thought was the meaning of the word or provision. ${ }^{2}$ The Origination Clause reads as follows:

All Bills for raising Revenue shall originate in the House of Representatives; but the Senate may propose or concur with Amendments [on House bills for raising revenue] as on other Bills. ${ }^{3}$

Natelson examined the Origination Clause relative to the Patient Protection and Affordable Care Act (PPACA or the Affordable Care Act) because several lawsuits alleged PPACA violates this clause.

1 Robert G. Natelson, The Founders' Origination Clause and Implications for the Affordable Care Act, 38(2) Harvard J. L. \& Pub. Pol. 629 (2015) [hereinafter Natelson, Origination Clause].

2 See generally Robert G. Natelson, The Founders' Hermeneutic: The Real Original Understanding of Original Intent, 68 Онго Sт. L.J. 1239-1305 (2007) [hereinafter Natelson, Founders' Hermeneutic].

$3 \quad$ U.S. CONST. art. I, $§ 7$. 
In 2012, the Pacific Legal Foundation (PLF) launched one such lawsuit with Sissel v. United States Department of Health \& Human Services, ${ }^{4}$ although this lawsuit ultimately failed. ${ }^{5}$ Sissel was a reaction to the decision by the Supreme Court earlier that year in National Federation of Independent Business (NFIB) $v$. Sebelius. The Court declared the individual mandate in PPACA was constitutional only because it was a valid exercise of Congress' power to tax. ${ }^{6}$ In 2014 , it was estimated the individual mandate raises $\$ 5$ billion in revenue every year by fining individuals and families who do not purchase health insurance. ${ }^{7}$ PPACA also contains several other taxes, such as the additional Medicare tax and the medical device tax, and many health regulations and appropriations.

As PLF noted, the Senate originated the individual mandate and the rest of PPACA by amending House Resolution (H.R.) 3590, titled the Service Members Home Ownership Tax Act of 2009. ${ }^{8}$ No part of the Service Members bill would have regulated health care. The bill would have, among other actions, granted tax credits to service members seeking their first homes and temporarily increased estimated tax payments for certain companies. The Senate's amendment to the Service Members bill completely replaced the bill's title and text with PPACA's title and text. All that remained was the number of the Service Members bill. ${ }^{9}$ With the Senate's amendment, a 6-paged House bill became the 2,407-paged PPACA. PLF argued the individual mandate was a bill for raising revenue that originated in the Senate, not the House, and therefore violates the Origination Clause. PLF further argued that, as the individual mandate is essential to the implementation of PPACA, courts should invalidate all of PPACA. ${ }^{10}$

\section{A. NATELSON'S ARGUMENT}

Before examining Natelson's argument regarding the Origination Clause and PPACA, it is important to note his methodology for discovering the original understanding of a constitutional word or provision. Natelson's book titled The Original Constitution: What It Actually Said and Meant ( $2^{\mathrm{d}}$ ed., 2011) outlines his methodology, ${ }^{11}$ which is primarily to analyze the debates among the 1,648 ratifiers of the Constitution at the

$4 \quad$ See generally Amended Complaint for Declaratory Judgment and Injunctive Relief, Matt Sissel v. United States Department of Health and Human Services, 2012 Case No. 10-1263 (BAH) (D.D.C. 2013) [hereinafter Amended Complaint].

5 See, e.g., Tom Howell, Jr., Supreme Court Refuses to Take another Obamacare Case (January 19, 2016), available at http://www.washingtontimes.com/news/2016/jan/19/ supreme-court-refuses-take-another-obamacare-case/.

6 Nat'l Fed. of Independent Business v. Sebelius, 132 S.Ct. 2566 (2012).

7 Congressional Budget Office, Payments of Penalties for Being Uninsured Under the Affordable Care Act: 2014 Update, June 2014, available at https://www.cbo.gov/publication/45397.

8 H.R. 3590, 111th Cong. (2009).

9 Daniel Smyth, The Origination Clause: Die Harder, ObamaCare! (October 19, 2012), available at http://www.americanthinker.com/articles/2012/10/the_origination_clause_ die_harder_obamacare.html. Compare the Service Members Home Ownership Tax Act of 2009, H.R. 3590, $111^{\text {th }}$ Congress (2009), with Amendments to H.R. 3590, $111^{\text {th }}$ Congress (passed December 24, 2009).

10 Amended Complaint, supra note 4, at 6, 12.

11 Robert G. Natelson, The Original Constitution: What It Actually Said and Meant 29-41 (2d ed., 2011) [hereinafter Natelson, Original Constitution]. 
13 state conventions held between 1787 and 1790. To provide background and help illuminate the original understanding of a constitutional word or provision, Natelson analyzes records from relevant settings during the founding era. For instance, Natelson often examines relevant practices and procedures of the British parliament in the eighteenth century. The parliament's practices and procedures heavily influenced the writing of the Constitution. ${ }^{12}$ Natelson also often examines the recorded views of the Constitution's framers, who were the delegates to the Philadelphia Convention of 1787. The Convention assembled for what many founders, who included the ratifiers, the framers, and the others who significantly influenced the proposal or ratification process of the Constitution, ${ }^{13}$ and others had understood to be the purpose of amending the Articles of Confederation. ${ }^{14}$ The Articles was the legal compact between 13 states enacted in 1781 in which each state was equally responsible for national affairs. The expectation was that amendments would simply add powers to the Confederation Congress, such as the power to regulate interstate trade. However, during the Philadelphia Convention, many framers evidently came to believe the Articles was an insufficient document for having an effective system of government. Instead of simply adding powers to the Confederation Congress, the Philadelphia Convention proposed the Constitution to replace the Articles. ${ }^{15}$

In his article on the Origination Clause, Natelson argued the original understanding of a bill for raising revenue is any bill that derives its constitutional authorization exclusively from Congress' power to tax and that increases or reduces taxes or otherwise changes tax laws. Natelson claimed the individual mandate should be considered to have been a bill for raising revenue only because the Supreme Court in effect ruled, in NFIB, that the individual mandate was such a bill. Natelson claimed the Service Members bill was a bill for raising revenue according to the original understanding of that term because the Service Members bill derived its constitutional authorization exclusively from Congress' power to tax and would have reduced taxes for service members while "effectively rais[ing]" taxes on certain companies. ${ }^{16}$

Natelson, Original Constitution, supra note 11, at 14-15.

Id. at 10 .

In an online essay, Natelson noted that, contrary to popular opinion, states-not the Confederation Congress - authorized the Philadelphia Convention. Natelson argued the states thereby held the Convention "outside the framework of the Articles [of Confederation.]" According to Natelson, most of the 13 states in the confederation gave their respective representatives to the Convention enough power to permit the Convention to completely replace the Articles. For instance, Natelson said the following: "[Most of the states'] calls provided for the [Philadelphia] [C]onvention to propose changes in the 'federal constitution' without limiting the gathering to amendments to the Articles. The unanimous authority of 18 th century dictionaries tells us that 'constitution' in this context meant the entire political system, not merely the Articles as such." See Rob Natelson, The Constitutional Convention Did Not Exceed Its Power and the Constitution is not "Unconstitutional" (June 2, 2013), available at https://www.i2i.org/the-constitutionalconvention-did-not-exceed-its-power-and-the-constitution-is-not-unconstitutional/. Regardless, as shown in my article, the understanding of many founders and others was that the Philadelphia Convention would amend and not completely replace the Articles.

15 See generally Jack N. Rakove, The Collapse of the Articles of Confederation, in THE American Founding: Essays on the Formation of the Constitution 225-44 (J. Jackson Barlow, Leonard W. Levy, \& Ken Masugi eds., 1988) [hereinafter Rakove, Collapse].

16 Natelson, Origination Clause, supra note 1, at 706-07. 
Natelson also examined the original understanding of amendment, as (emphasis added) "the Senate may propose ... Amendments [on House bills for raising revenue] as on other Bills." According to Natelson, if the original understanding of amendment permits complete substitutes, then parts or all of PPACA could comply with the original understanding of the Origination Clause. Natelson said a complete substitute occurs when "all the language in a bill or resolution after the enacting clause (or after some other clause very early in the text) [i]s removed and replaced with new language."17

In analyzing records of the Philadelphia Convention, state legislatures, state conventions, and other settings, ${ }^{18}$ Natelson found evidence that the original understanding of amendment was a germane (i.e., of the same subject) change to legislation that could be a complete substitute. ${ }^{19}$ Natelson argued the Senate can meet the germaneness requirement for a complete substitute to a House bill for raising revenue by simply making the complete substitute a tax(es). Natelson noted such a complete substitute could not add regulations, appropriations, or other non-taxes to the original bill. ${ }^{20}$

Thus, Natelson said the Senate could, as an amendment, completely replace the House's Service Members bill with the individual mandate and other taxes in PPACA. Natelson declared that PPACA's other parts, including its health regulations and appropriations, were non-germane to the original bill and therefore in violation of the original understanding of amendment.

Natelson thereby concluded the individual mandate and other taxes in PPACA amounted to a valid amendment to - and thus a continuation of - the Service Members bill. Natelson claimed these parts of PPACA therefore originated in the House as that bill for raising revenue and comply with the original understanding of the Origination Clause. ${ }^{21}$

\section{B. MY ARGUMENT}

As do many constitutional scholars, ${ }^{22}$ I consider the original public meaningnot the original understanding - of a constitutional word or provision, unless unrecoverable, to be the controlling meaning of that word or provision. The original public meaning is the meaning that a "reasonable speaker of English" during the founding era would have ascribed to the word or provision. ${ }^{23}$ The original understanding and original public meaning of a constitutional word or provision are often identical, but a conflict is possible. ${ }^{24}$

\footnotetext{
Id. at 682 .

Id. at $680-705$.

Id. at 706 .

Id.

Id. at 706-09.

22 See, e.g., Randy E. Barnett, Restoring the Lost Constitution: The Presumption OF LiBERTY 89-130 (2004); Gary Lawson \& Guy Seidman, Originalism as a Legal Enterprise, 23 Const. Comment. 47-80 (2006); Larry Solum, Semantic Originalism, Illinois Public Law and Legal Theory Research Papers Series No. 07-24 (November 22, 2008), available at $\mathrm{http} / / /$ papers.ssrn.com/sol3/papers.cfm?abstract_id $=1120244$

23 Randy E. Barnett, The Gravitational Force of Originalism, 82 FordHAm L. REv. 415, 417 (2013).

24 As one example, Natelson noted there appears to be a conflict between the original understanding and original public meaning of the ex post facto clauses. See Natelson, Founders' Hermeneutic, supra note 2, at 1243-45.
} 
My article does not examine the original public meaning of a bill for raising revenue and whether the individual mandate, other taxes in PPACA, or Service Members bill complied with this meaning of a bill for raising revenue. However, to examine whether PPACA was a valid amendment to the Service Members bill according to the original public meaning of amendment, my article assumes the individual mandate or another tax(es) in PPACA and the Service Members bill complied with the original public meaning of a bill for raising revenue. Assuming otherwise would make my examination of the amendment question unnecessary. If the individual mandate or another tax(es) in PPACA did not comply with the original public meaning of a bill for raising revenue, then according to my originalist method the Origination Clause would not apply to PPACA. If the Service Members bill did not comply with that meaning of a bill for raising revenue and the individual mandate or another tax(es) in PPACA did comply therewith, then according to my originalist method it would be impossible to argue that PPACA was the continuation of a House bill for raising revenue. It would be evident that PPACA represented a new bill for raising revenue that originated in the Senate.

My article argues the original public meaning of amendment is clear and disallows complete substitutes. Therefore, PPACA or any other complete substitute by the Senate to a House bill for raising revenue that is a new bill for raising revenue violates the original public meaning of the scope of an amendment. Furthermore, my article argues the preponderance of evidence suggests the original understanding of the scope of an amendment actually disallows complete substitutes.

Part II explores the original public meaning of amendment. Part III rebuts Natelson's claim that the original understanding of the scope of an amendment permits complete substitutes. Specifically, Part III presents evidence from the British parliament in the eighteenth century that shows the parliament most likely disallowed amendments on bills to be complete substitutes in the decades leading up to the founding. Part III then examines the origination of the Constitution at the Philadelphia Convention and the Constitution's ratification process to show the dominant view among the founders was that an amendment to the Articles of Confederation could not be a complete substitute. During the ratification process, the Confederation Congress was the first body to consider the Constitution, followed by the state legislatures and then state conventions. The Articles was a legal document ratified by 13 states, and therefore discussions by the founders about the permissible scope of an amendment to the Articles reflected what they thought was the permissible scope of an amendment to legislation, such as bills, resolutions, and existing laws. ${ }^{25}$ As appropriate, Part III evaluates the evidence Natelson used to argue the original understanding of the scope of an amendment permits complete substitutes. The Conclusion summarizes my evidence versus Natelson's evidence, defines a complete substitute according to the original public meaning of the scope

25 I found no evidence that suggests the founders or others distinguished between the permissible scope of an amendment to the Articles of Confederation and the permissible scope of an amendment to legislation. My finding is thus consistent with Natelson's finding that "[i]n America ... how the word [amend] was used [by the founders and legislators during the founding era] did not hinge on the nature of the item being amended." As Natelson noted, it did not matter whether, for example, "th[e] item [being amended] was a bill from the same house, a bill from the other house, a resolution, a report, or a prior law." See Natelson, Origination Clause, supra note 1, at 658, 681. 
of an amendment, and explains exactly how PPACA or any other such complete substitute violates this meaning of the scope of an amendment.

It should be noted that my research found several discussions by "reasonable speakers of English" and founders about how alterations, revisions, or repairsnot just amendments - to the Articles of Confederation could not be complete substitutes. The reason is that technically the Articles permitted alterations - not amendments - to itself. ${ }^{26}$ And before the Philadelphia Convention assembled, the Confederation Congress had given the convention the mission of revising and altering the Articles. ${ }^{27}$ It was simply the case that "reasonable speakers of English" and the founders often referred to the Philadelphia Convention's power to alter or revise the Articles as the power to amend the Articles.

For several reasons, my article includes these discussions about how alterations, revisions, or repairs to the Articles could not be complete substitutes as evidence of the original public meaning of amendment and original understanding of the scope of an amendment. For one, regarding the word alteration in particular, foundingera dictionaries consistently defined "alter" (to change, vary, or make something different) as a concept that was similar to but more expansive than "amend" (to correct or grow better) ${ }^{28}$ and several dictionaries actually defined "amendment"

ARTICLES OF CONFEDERATION art. XIII.

See infra Part III (discussing the context of the Philadelphia Convention).

28 Compare the definitions of "amend" in Part II with the following definitions of "alter." Of 10 commonly-cited, regular dictionaries from the founding era, the following six dictionaries defined "alter" as to change, vary, or make something different:

- John Ash, the New and Complete Dictionary of the English Language (London, 1775) [hereinafter AsH].

- Thomas Dyche \& William Pardon, A New General English Dictionary (London, 18th ed. 1781) [hereinafter DYche \& PARDON].

- William Perry, The Royal Standard English Dictionary (Worcester, 1st Am. ed. 1788) [hereinafter PERRY].

- Thomas Sheridan, A Complete Dictionary of the English Language (2 volumes, London, 3d ed. 1790) [hereinafter SHERIDAN].

- John Walker, A Critical Pronouncing Dictionary (London, 1791) [hereinafter Walker].

- Frederick Barlow, The Complete English Dictionary (2 volumes, London, 177273) [hereinafter BARLOW].

The following two dictionaries explicitly stated "alter" did not mean "to completely replace" but was nevertheless an expansive concept (emphasis added):

- Samuel Johnson, A Dictionary of the English Language (London, 1755) [hereinafter JoHnson]: 1) "To change; to make otherwise than it is. To alter, seems more properly to imply a change made only in some part of a thing; as, to alter a writing, may be, to blot or interpolate it; to change it, maybe, to substitute another in its place," 2) "To become otherwise than it was; as, the weather alters from bright to cloudy."

- William Kenrick, A New Dictionary of the English Language (London, 1773) [hereinafter KenRICK]: 1) "To change; to make otherwise than it is. To alter, seems more properly to imply a change made only in some part of a thing, as, to alter a writing, may be, to blot or interpolate it; to change it, may be, to substitute another in its place," 2) "To become otherwise than it was."

Only the following dictionary suggested "alter" could be "to completely replace" (emphasis added):

- James Barclay, Complete and Universal English Dictionary (London, 1792) [hereinafter BARCLAY]: "To change; to make a thing different from what it is; used both of a part and the whole of a thing, and applied both in a good and bad sense. Used neuterly [sic], to change; to become different from what it has been." 
as a type of alteration that corrects something. ${ }^{29}$ Thus, it can be concluded that "reasonable speakers of English" and founders who argued that the power to alter disallowed complete substitutes would have argued the same for the lesser, related power to amend. Also, the founders and others often used the words alter and amend as synonyms..$^{30}$ Furthermore, it is reasonable to conclude from the text of the discussions about how revisions or repairs to the Articles could not be complete substitutes that these discussions used those words as synonyms for either the word alteration or the word amendment.

\section{The Original Public Meaning of Amendment}

To discover the original public meaning of amendment, I first examined numerous law and regular dictionaries from the founding era for their definitions of amendment and amend. Then, I analyzed the use of amend and words with the root of amend, such as amendment and amends, in articles, pamphlets, letters, and other writings in the most prominent compilations of records from the Constitution's ratification period, such as The Documentary History of the Ratification of the Constitution, ${ }^{31}$ The Federalist Papers, and The Complete Anti-Federalist. ${ }^{32}$

\section{A. Dictionary Definitions of Amendment}

I examined five legal dictionaries ${ }^{33}$ and 10 commonly-cited, regular dictionaries. ${ }^{34}$ No legal dictionaries defined "amendment" or its verb form "amend." Each regular dictionary defined "amendment" as a change or alteration to something that transformed the thing from bad to better. ${ }^{35}$ For instance, Samuel Johnson's $A$

This dictionary provided no definition of "alter":

- Nathan Bailey, The New Universal Etymological English Dictionary (4th ed., London, 1756) [hereinafter BAILEY].

29 See infra Part II (defining the word amendment).

30 Natelson, Origination Clause, supra note 1, at 681.

31 The Documentary History of the Ratification of the Constitution Digital Edition (John P. Kaminski, Gaspare J. Saladino, Richard Leffler, Charles H. Schoenleber \&Margaret A. Hogan eds., 2009) [hereinafter Documentary History Digital].

32 The Complete Anti-Federalist (Herbert Storing ed., 1981) [hereinafter Complete AntiFederalist].

33 Richard Burn \& John Burn, A New Law Dictionary (2 volumes, London, 1792); Timothy Cunningham, A New And Complete Law-Dictionary (London, S. Crowder et al. 1764) (two volumes); Giles Jacob, A New Law Dictionary (6th ed. 1750); Thomas Blount, A Law-Dictionary And Glossary (1717); John Cowell, A Law Dictionary Or THE INTERPRETER (1777).

34 See supra note 28.

35 Aside from the definitions of "amendment" mentioned in the text, the relevant definitions are as follows:

- Perry, supra note 28: "A change for the better"

- Sheridan, supra note 28: 1) "A change from bad for the better," and 2) "in law, the correction of an errour [sic] committed in a process." 
Dictionary of the English Language (1755), the most widely used dictionary at the ratification of the Constitution, defined "amendment" as a "change from bad for the better" and "signifies, in law, the correction of an error committed in a process." ${ }^{36}$ John Ash's The New and Complete Dictionary of the English Language (1775) stated "amendment" was a "change for the better, a reformation, a recovery" and "[i]n law, the correction of an error in a process." ${ }^{37}$ According to Thomas Dyche and William Pardon's A New General English Dictionary (1781), an "amendment" involved "improving, growing, better correcting what is amiss" and "in law, it is rectifying or supplying a mistake or omission to a process." 38

Regular dictionaries defined "amend" as "to correct," "to grow better," or a similar phrase. ${ }^{39}$ And several dictionaries further noted, as Johnson's dictionary did, that " $[\mathrm{t}] \mathrm{o}$ amend differs from [to] improve; to improve supposes or not denies that the ... [thing being amended] is well already, but to amend implies something wrong." 40

- WALKer, supra note 28: 1) "A change from bad for the better," and 2) "in law, the correction of an errour committed in a process."

- BARLOW, supra note 28: 1) "An alteration for the better; a correction," and 2) "Applied to the constitution, it signifies a change from sickness towards health: a recovery."

- KenRICK, supra note 28: 1) "A change from bad for the better," and 2) "It signifies, in law, the correction of an error committed in a process."

- BARCLAY, supra note 28: 1) "An alteration which makes it better; a correction," and 2) "It signifies a change from sickness towards health; a recovery."

- BAILEY, supra note 28: Bailey does not define "amendment." However, he mentions the word "amendement" [sic] in the definition of "amendableness," which he defined as follows: "(of amendement...) capableness of being amended."

JoHNSON, supra note 28.

Ash, supra note 28.

DYCHE \& PARDON, supra note 28.

The relevant definitions of "amend" are as follows:

- Johnson, supra note 28: 1) "To correct; to change any thing that is wrong to something better," and 2) "To grow better."

- Ash, supra note 28: "To correct, to reform, to restore; to grow better."

- Dyche \& PARDON, supra note 28: "to improve in art, to reform or correct what has been done amiss, to behave better than heretofore."

- Perry, supra note 28: "to correct, to grow better."

- Sheridan, supra note 28: 1) "to correct, to change any thing that is wrong," and 2) "to grow better."

- WALKER, supra note 28: 1) “To correct, to change any thing that is wrong," and 2) "to grow better."

- BARLOW, supra note 28: 1) "to alter for the better," 2) "to correct," 3) "to reform," and 4) "used neuterly [sic] and applied to both, to grow from a more infirm state to a better; to recover."

- KenRicK, supra note 28: 1) "To correct; to change any thing that is wrong to something better," and 2) "To grow better."

- BARCLAY, supra note 28: "to alter something faulty for the better. Applied to writings, to correct... To grow from a more infirm state to a better; to recover."

- Balley, supra note 28: Bailey provided no definition of "amend." However, Bailey defines "to mend" as follows: 1) "To repair from breach or decay," 2) "To correct, to alter for the better," 3) "To help, to advance," and 4) "To improve, to increase." In another entry for "To Mend," Bailey provides these definitions: "to grow better, to advance in any good, so to be changed for the better."

40 Johnson, supra note 28. Besides Johnson's dictionary, the following two dictionaries distinguished between "amend" and "improve": 
Of course, the implication of all these definitions of "amendment" and "amend" is that an amendment must be germane to what is being amended, as correcting something requires relevant changes. Also, an amendment must preserve at least a part of the thing being amended so that there is something to transform from bad to better.

\section{B. Articles, Pamphlets, Letters, and Other Writings}

I searched for every occurrence of amend and words with the root of amend in the following, prominent compilations of records from the Constitution's ratification period: The Documentary History of the Ratification of the Constitution, The Federalist Papers, Friends of the Constitution: Writings of the "Other" Federalists ${ }^{41}$ The Complete Anti-Federalist, and The Anti-Federalist Papers. ${ }^{42}$ These compilations contain articles, pamphlets, letters, and other writings that can reveal how "reasonable writers of English" used and understood words and phrases from the Constitution in different contexts. Also, many writings in these compilations were main sources of information for "reasonable readers of English" during the ratification period.

\section{Amendments Could Not Be Complete Substitutes}

The compilations of records abound with over 60 examples of writings, most of which concern the Articles of Confederation, suggesting amendments could not be complete substitutes. Since my examples are so numerous, the Appendix lists those not discussed in my article. My examples are consistent with the evidence presented in the recent article on the Origination Clause by Professor Priscilla Zotti and scholar Nicholas Schmitz. Their article documented numerous examples of writings from the ratification period, and none to the contrary, suggesting the original public meaning of the Origination Clause did not contemplate the possibility that the Senate could originate revenue bills in any way, including as complete substitutes. ${ }^{43}$ For example, Zotti and Schmitz noted an American Citizen, in an article in the Philadelphia Independent Gazetteer on September 28, 1787, argued that " $[\mathrm{t}]$ hey [the Senate] may restrain the profusion of errors of the [H]ouse

- $\quad$ BARlow, supra note 28: "This word ['amend'] and 'improve,' are very far from being synonymous, tho' they are often used promiscuoutly [sic]; for amend carries with it the secondary idea of some preceding defect, or fault; but improve though it implies the advancing to a greater degree of perfection, does not imply that the precedent state was culpable; for a person may be virtuous and still improve in virtue.

- $\quad$ KENRICK, supra note 28: "To amend differs from to improve; to improve supposes or not denies that the thing is well already, but to amend implies something wrong."

41 Friends of the Constitution: Writings Of The "Other” Federalists (Sheehan \& McDowell, eds., 1998) [hereinafter Friends of the Constitution].

42 The Anti-Federalist Papers (Morton Borden ed., 1965) [hereinafter Anti-Federalist PAPERS].

43 Priscilla H.M. Zotti \& Nicholas M. Schmitz, The Origination Clause: Meaning, Precedent, and Theory from the $12^{\text {th }}$ to $21^{\text {st }}$ Century, 3 BR. J. AM. LEG. STUdies 116, 135-39 (2014) [hereinafter Zotti \& Schmitz, Origination Clause]. 
of [R]epresentatives [regarding a bill for raising revenue], but they [the Senate] cannot take the necessary measures to raise a national revenue." ${ }^{44}$

Among the over 60 examples that I found are a few from Federalists regarding the Origination Clause that suggest the Senate's amendment power was not so expansive as to permit complete substitutes. The first example is the article by Brutus, who is not to be confused with the popular Anti-Federalist of the same pseudonym, in the Virginia Journal on December 6, 1787. Brutus defended the new constitution against the criticisms of George Mason, which the journal published two weeks earlier. Among other criticisms, Mason disapproved of the new constitution's stipulation that states and not "the people" would elect senators. According to Mason, this stipulation made the Senate unaccountable to "the people." Mason claimed the Senate's powers, such as its power to amend bills for raising revenue, could destroy people's liberty. Brutus countered that the Senate's amendment power, which he called the "power of doing good," was necessary because the House could never make a bill "perfect in all its parts." 45 Brutus' language reflected that he agreed with the dictionaries' definitions of "amendment," described above, as a change or alteration to something that transforms the thing from bad to better. Brutus also said the Senate could "go no further" than proposing amendments, suggesting that the amendment power substantially limited the Senate in affecting a House bill for raising revenue.

A second example is Marcus' article in the Norfolk and Portsmouth Journal of Virginia on February 20, 1788. His article was another response to George Mason's criticisms of the new constitution. Marcus said Mason should be unconcerned with the Senate's amendment power because the House must (emphasis added) "originate all money bills" while "[t]he wisdom of the Senate may sometimes point out amendments, the propriety of which the ... House [of Representatives] may be very sensible of, though they had not occurred to [the House]." ${ }^{46}$ These comments suggest Marcus thought of an amendment as only a correction to a bill, not as a procedure by which the Senate could originate its own revenue bills.

A third example is a Native of Virginia's pamphlet titled Observations upon the Proposed Plan of Federal Government, which was published on April 2, 1788. This pamphlet rebutted many Anti-Federalists' objections to the new constitution. Before addressing the Origination Clause, a Native of Virginia remarked that the Philadelphia Convention was supposed to have amended the Articles of Confederation but, noticing so many "radical defects," decided to "new-model the Federal Constitution." Here, a Native of Virginia implied the Convention did not amend but rather completely replaced the Articles with a new model. Later in the pamphlet when a Native of Virginia discussed the Origination Clause in a general sense, he said "the Senate cannot originate ... bills [for raising revenue]" but "have the power of amending them." ${ }^{47}$ Thus, considering a Native of Virginia's remarks about the Articles and Origination Clause, if the Senate noticed "radical defects" in a House bill for raising revenue and completely

$44 \quad I d$. at 135.

45 Brutus, Virginia Journal, 6 December 1787, reprinted in Documentary History Digital, supra note 31.

46 Marcus I, Norfolk and Portsmouth Journal, 20 February 1788, reprinted in DocumENTARY History Digital, supra note 31.

47 A Native of Virginia: Observations upon the Proposed Plan of Federal Government, 2 April 1788, reprinted in Documentary History Digital, supra note 31. 
replaced it with a "new model" then the replacement would be an origination and not an amendment.

Of the numerous examples of writings suggesting amendments to the Articles of Confederation could not be complete substitutes, several examples allegorized the Articles to make the point. One example involves the popular pamphlet of letters written by the Federal Farmer, who was actually an Anti-Federalist, titled Observations Leading to a Fair Examination of the System of Government Proposed by the Late Convention. In a letter dated November 8, 1787, the Federal Farmer discussed the circumstances leading up to the Philadelphia Convention, saying that "had the idea of a total change [to the Articles] been started, probably no state would have appointed members to the convention." The Federal Farmer continued his letter with the following ship allegory for the Articles (emphasis added):

[Leading up to the Philadelphia Convention,] not a word was said about destroying the old constitution, and making a new one-The states still unsuspecting, and not aware that they were passing the Rubicon [river] [i.e., the point of no return], appointed members to the new convention, for the sole and express purpose of revising and amending the confederation-and, probably, not one man in ten thousand in the United States, till within these ten or twelve days, had an idea that the old ship was to be destroyed, and he put to the alternative of embarking in the new ship presented, or of being left in danger of sinking[.] $]^{48}$

According to the Federal Farmer, the Articles was the old ship that, after passing the Rubicon, was not fixed but destroyed and replaced with a new ship.

Ship News, in an article in the Boston Gazette on February 4, 1788, used another ship allegory for the Articles. Ship News described two ships, one named Confederation and the other Constitution. Confederation fit this description:

[It] is a very leaky weak vessel, built at a time when season'd timber could not be procured; the necessity of her being built immediately was the cause of the Builders throwing her so slightly together, and not more firmly and consistently uniting the various parts. That many of her planks are rotten; that her timbers in many parts are defective; that should she engage an enemy of one third of her guns, on the reception of the first well-aim'd broadside, she would be effectually ruined: in short, that she is beyond repair.

Ship News said Constitution, by contrast, was "beautiful," "far superior to any [other ship]," and "well calculated for ... American service."49 Thus, Ship News implied that nothing from the Articles was salvageable and therefore no alteration or amendment was possible and America needed the new constitution.

Another popular allegory was Federalist Francis Hopkinson's "The New Roof," published in the Pennsylvania Packet on December 29, 1787. Hopkinson discussed

48 Federal Farmer, Letters to the Republican-- Letter I, 8 November 1787, reprinted in Documentary History Digital, supra note 31.

49 Ship News, Boston Gazette, 4 February 1788, reprinted in Documentary History DigiTAL, supra note 31. 
how the roof of a family's mansion, representing the Articles, needed repairs. The family invited "skillful architects," representing the Federalists at the Philadelphia Convention, to inspect the roof. The architects found major problems, such as a weak frame and unconnected rafters, and decided the following:

$[\mathrm{T}]$ hat it would be altogether vain and fruitless to attempt any alterations or amendments in a roof so defective in all points; and therefore proposed to have it entirely removed, and that a new roof of a better construction should be erected over the mansion house.

The architects then proposed a plan to install a new roof, which represented the new constitution and which the family would have to consider. ${ }^{50}$ This part of Hopkinson's allegory demonstrated the new constitution, as a complete substitute to the Articles, was not an amendment but a new proposal.

Many other examples, mostly from Anti-Federalists, argued the Philadelphia Convention's amendment power disallowed complete substitutes to the Articles. One example is a letter by Robert Yates and John Lansing, representatives of New York at the Philadelphia Convention, to George Clinton, governor of that state, on December 21, 1787. Describing why they opposed the new constitution, Yates and Lansing said, among other arguments, that the Philadelphia Convention "exceed[ed] the powers delegated to us" by, instead of amending the Articles, proposing a "general Constitution in subversion of ... the [Articles.]" Yates and Lansing further said the (emphasis added) "leading feature of every amendment ought to [have] be[en] the preservation of the individual States, in their uncontroled [sic] constitutional rights" along with grants of additional powers, such as the power to regulate commerce, to the Confederation Congress. ${ }^{51}$

Cato, a popular Anti-Federalist, provides another example with his article in the New York Journal on October 11, 1787. Cato said the framers had power only to revise and alter the Articles but "exceeded the authority given to them" as follows:

[The framers] transmitted to [the Confederation] Congress a new political fabric [the new constitution], essentially and fundamentally distinct and different from it [the Confederation], in which the different states do not retain ... their sovereignty and independency [sic], united by a confederated league[.]

Then, Cato emphasized the "new government" consisted of a national structure and powers "not known to the articles of confederation." Cato further claimed the framers proposed the new constitution under an "assumption of power [and therefore not under the amendment power]" and "in usurpation." 52

In an article in the Massachusetts Centinel on January 12, 1788, the Republican Federalist, who was another Anti-Federalist with a contradictory pseudonym,

50 The New Roof, Francis Hopkinson, Pennsylvania Packet, 29 December 1787, reprinted in Documentary History Digital, supra note 31.

51 Robert Yates and John Lansing, Reasons of Dissent, New York Journal, 14 January 1788 , reprinted in Documentary History Digital, supra note 31.

52 Cato II, New York Journal, 11 October 1787, reprinted in Documentary History DigiTAL, supra note 31. 
lamented how the Philadelphia Convention, instead of amending the Articles, "reported a system ... which destroys the $[\mathrm{A}] \mathrm{rticles}$... and completely embraces the consolidation of the union[.]" Echoing Cato, the Republican Federalist blasted the "new system" as "founded in usurpation," "unauthorized ... unexpected," and "not merely an innovation, but an interchange of the 'established form' of government." 53

In the same article, the Republican Federalist gave the following warning given what he perceived as a precedent for permitting an amendment to be a complete substitute (emphasis added):

But supposing a Convention should be called [to amend the new constitution], what are we to expect from it, after having ratified the proceedings of the late federal [Philadelphia] Convention? They will be called to make 'amendments' an indefinite term, that may be made to signify any thing... [P]erhaps ... [someone] will think a system of despotism ... [to be a good] amendment to the present plan [the new constitution], and should the next change be only to a monarchial government, the people may think themselves very happy[.] $]^{54}$

According to the Republican Federalist, the Philadelphia Convention had corrupted the definition of amendment to permit complete substitutes and amendments could now "signify any thing."

Another example involves Anti-Federalist Silas Lee's letter to Federalist George Thatcher on February 14, 1788. The following excerpt made a similar warning as the Republican Federalist's article (emphasis added):
But I hope the precedent of the late federal [Philadelphia] Convention will not be followed by the next [convention to amend the new constitution] that may be appointed; viz instead of revising or amending this [new constitution] in certain parts ... they will not with one Stroke wipe the whole away ... \& propose a new one [.] $]^{55}$

Lee thereby suggested the Philadelphia Convention violated its amendment power by proposing a new constitution.

An additional example is Exeter, N.H.'s article in the Freeman's Oracle of New Hampshire on March 21, 1788. Exeter, N.H., said the Philadelphia Convention discovered the "impropriety of attempting an amendment of the Confederation" and therefore pursued a "Government of these States de novo ... proceeding upon original principles." Exeter, N.H., emphasized that, in proposing a complete substitute to the Articles, the framers could not "ac[t] in their official characters, upon the [amendment] powers given them by the respective states[.]" In Exeter, N.H.'s opinion, the framers were instead acting as "private persons inspired with disinterested love to [sic] their country[.."'56

53 The Republican Federalist IV, Massachusetts Centinel, 12 January 1788, reprinted in Documentary History Digital, supra note 31.

$54 \quad$ Id.

55 Silas Lee to George Thatcher, Biddeford, 14 February 1788, reprinted in DocumENTARY History Digital, supra note 31.

56 Exeter, N.H., Freeman's Oracle, 21 March 1788, reprinted in Documentary History DigitaL, supra note 31. 
An example from the South involves a Georgian's article in the Gazette of Georgia on November 15, 1787. He said the Philadelphia Convention's only power was to alter the Articles, so the Convention should have simply entrusted the Confederation Congress with such additional powers as regulating foreign and internal trade. A Georgian remarked that the Convention instead "thought fit to destroy such an [sic] useful fabrick [sic], as the [A]rticles ... and, on the ruins of that, raised a new structure[.]" 57

Several more examples involve three towns' instructions to their respective representatives at the Massachusetts Convention. On November 26, 1787, the Town of Grate Barrington directed representative William Whiting to oppose the new constitution given these two reasons (emphasis added and the original text included all the spelling errors):

First as the Constitution of this Commonwealth Invests the Legslature with no such Power as sending Delligates To a Convention for the purpose of framing a New System of Fedderal Goverment-we conceive that the Constitution now offered us is Destituce of any Constituenal authority either states or fedderal.

2nd had the Delligates from this state been Constituenaly appointed yet their Commission extended no further than the Revising and amending the former articles of Confedderation-and therefore they could not pretend to the Least Colour of Right or authority from their Principles to Draw up a new form of Fedderial Goverment. ${ }^{58}$

Thereby, the Town of Grate Barrington stated the Convention's amendment power disallowed complete substitutes, such as the new constitution.

On December 16 of the same year, the town of Harvard told representative Josia Witney to "give your negative vote" to the new constitution. The town explained that (emphasis added) "amendments may be made upon the Confederation of the United States, by vesting Congress with greater Powers, [but] without so totally changing and altering the same, as the proposed Constitution has a tendency to." 59

Two weeks later on December 31, the town of Townshend recommended that representative Daniel Adams support the new constitution with certain amendments, such as the addition of a declaration of rights. However, the town also noted the Philadelphia Convention was supposed to have only amended the Articles "yet ... instead of that [amendment] ... Sent out a [new] fraim [sic] of government[.]"60

\footnotetext{
57 Essay by A Georgian, Gazette of the State of Georgia, 15 November 1787, reprinted in Documentary History Digital, supra note 31.

58 Town of Grate Barrington's (Massachusetts) Draft Instructions, 26 November 1787, To William Whiting Esq., reprinted in Documentary History Digital, supra note 31.

59 Town of Harvard's (Massachusetts) Instructions, 17 December 1787, To Josiah Witney, Esq., reprinted in Documentary History Digital, supra note 31.

60 Town of Townshend's [Townsend's] (Massachusetts) Instructions, 31 December 1787 To Capt. Daniel Adams - , reprinted in Documentary History Digital, supra note 31.
} 


\section{Amendments Had to Preserve Something}

Several examples from Anti-Federalists emphasized that, if the new constitution had preserved a part(s) of the Articles of Confederation, then the Philadelphia Convention may have avoided exceeding its amendment or alteration power. In the Virginia Independent Chronicle on June 11, 1788, Denatus said the framers failed to amend the Articles and instead built an entirely new constitution "after their own fancies." Denatus noted that, "[h]ad they [the framers] preserved only one article of the union [the Articles], and built the present [new] constitution to it, the objection of innovation would be unreasonable." ${ }^{\prime 61}$ On November 28, 1787, in his "A Review of the Constitution," a Federal Republican said that for the Philadelphia Convention to "frame a Constitution entirely new ... was out of their province." He continued that the framers should have "reserved that which was known to be good [in the Articles], and to have amended that only which was found defective from experience. ${ }^{62}$ In 1788, the Federal Farmer compared the Articles with the new constitution in another pamphlet of letters, titled An Additional Number of Letters from the Federal Farmer to the Republican. He said "there is no kind of similitude between the two [documents]," "[t] he new plan is totally a different thing," and "no part of the confederation ought to be adduced for supporting or injuring the new constitution." ${ }^{63}$ If, in the Federal Farmer's opinion, the new constitution preserved a significant part(s) or maintained a significant similarity to the Articles, then the new constitution could have qualified as an alteration or amendment to the Articles.

Several other examples, all from Federalists, countered that the new constitution did, in fact, preserve enough of the Articles to qualify as an alteration or amendment and to thereby not be a complete substitute. On January 16, 1788, State Soldier's article in the Virginia Independent Chronicle argued the new constitution, as an alteration and amendment to the Articles, preserved parts of the Articles while adding necessary "energy and power." He mentioned some preserved parts were the union among states, the credit of the union, a stipulation for appropriating "monies under pretence [sic] of providing for our national defence [sic]," and "state security for ... rights," such as "liberty of the press."

Two days later in the New York Packet, James Madison, writing as Publius, made an argument similar to State Soldier's. Madison argued the Philadelphia Convention's alteration power disallowed complete substitutes but included the power to "change the title; to insert new articles; [and] to alter old ones." Madison maintained the new constitution was not "absolutely new" but rather the "expansion of principles which are found in the articles of Confederation." For instance, Madison claimed the new constitution protected the state independence found in the Articles. Also, the new constitution required the state legislatures-not "the people"- to elect Senators, and this process was similar to how state legislatures

61 Denatus, Virginia Independent Chronicle, 11 June 1788, reprinted in DocumenTARY HisTORY DigitaL, supra note 31.

62 A Federal Republican, A Review of the Constitution, 28 November 1787, reprinted in DOCUMENTARY History Digital, supra note 31.

63 Federal Farmer, Letter X, January 7, 1788, reprinted in 2 Complete Anti-Federalist, supra note 32, at 283.

64 State Soldier; Essay I, Virginia Independent Chronicle, Richmond, 16 January 1788, reprinted in FRIENDS OF THE CONSTITUTION, supra note 41, at 115-17. 
elected all members of the Confederation Congress under the Articles. Madison claimed the Articles was "so feeble and confined" that it "require[d] a degree of enlargement which g[ave] to the new system the aspect of an entire transformation of the old." ${ }^{65}$ So, in Madison's opinion, the new constitution appeared to be a complete substitute but was only an extensive alteration to the Articles.

Colonel John Banister's article in the Petersburg Virginia Gazette on October 25,1787 , described a meeting of Petersburg residents at "Mr. Hare's tavern" about the new constitution. Banister noted all the attendees approved a resolution praising the new constitution as the Philadelphia Convention's valiant attempt to amend the Articles. The resolution described the new constitution as "a plan of government" that, among other accomplishments, "secure[d] the rights of the respective states [found in the Confederation]," "cement[ed] the union of the states [that the Confederation created]," and "extend[ed] an [sic] uniform administration of justice [that was in the Confederation]." The resolution stated the new constitution, in a general sense, was "founded upon the most enlarged principles [of the Confederation]." ${ }^{\prime \prime 6}$

A Citizen of Philadelphia's "Remarks on the Address of Sixteen Members," published on October 18, 1787, ${ }^{67}$ responded to "The Address of the [Sixteen] Seceding Assemblymen" in the Pennsylvania Packet in which 16 legislators from Pennsylvania described their opposition to the new constitution. ${ }^{68}$ In particular, a Citizen of Philadelphia contested the 16 assemblymen's claim that the new constitution exceeded the Philadelphia Convention's amendment power. He said "I suppose the whole force of their [the 16 assemblymen's] meaning must rest on the word amend." Then, he said the definition of an amendment within a legislative context was as follows (emphasis added):

[A]n amendment in the sense of legislative bodies, means either to strike out some words, clauses or paragraphs in a bill, without substituting any thing in the place of them, or to insert new words, clauses or paragraphs where nothing was inserted before; or to strike out some words, clauses or paragraphs, and insert others in their room, which will suit better[.]

Thereby, a Citizen of Philadelphia said the definition of amendment according to legislators permits the deletion or replacement of "some" - not "all" — parts of a bill. He then said, "I challenge the whole sixteen members to shew [sic] that the convention have done an iota more than this[.]" ${ }^{\prime 69}$ Thus, in a Citizen of Philadelphia's opinion, the new constitution was an amendment to the Articles and not a complete substitute.

In the New Haven Gazette on December 25, 1787, a Citizen of New Haven said the Convention was to "make amendments" and the "new constitution contain[ed] the powers vested in the federal government, under the former [Articles], with such additional powers as they deemed necessary to attain the ends the states had in view, in their appointment." He said preserved parts of the Articles included significant

\footnotetext{
65 The Federalist No. 40 (James Madison).

66 Colonel Banister, Petersburg Virginia Gazette, 25 October 1787, reprinted in DocumENTARY History Digital, supra note 31.

${ }^{67}$ A Citizen of Philadelphia, Remarks on the Address of Sixteen Members, 18 October 1787 (excerpt), reprinted in Documentary History Digital, supra note 31.

683 Complete Anti-Federalist, supra note 32, at 11.

69 A Citizen of Philadelphia, Remarks on the Address of Sixteen Members, 18 October 1787 (excerpt), reprinted in Documentary History Digital, supra note 31.
} 
state sovereignty from a national government, "the objects of expenditure," and "the number of members of Congress." 70

William Cushing of Massachusetts' undelivered speech dated February 4, 1788, made a claim similar to a Citizen of New Haven's. First, Cushing implied the new constitution was not an alteration or amendment to the Articles by saying (emphasis added and the original text included all the shorthand) "[s]ome Gentlemen sayAlter or amend the old Confederation - not make a new System, [but] why not make a new System, if yt. were necessary for ye. Salvation of ye Country?" However, Cushing then suggested the new constitution may have been a valid alteration and amendment to the Articles because (emphasis added and the original text included all the shorthand) "the Confederation, in appearance imparted many, if not most of the great powers, now inserted in the proposed Constitution; such as making war $\&$ peace, borrowing money without bounds upon ye. Credit of the united states,building \& equipping a navy—demanding men \& money without limitation—\& of appropriating money to defray the public expenses[.]"'71

\section{Amendments Could Be Extensive}

Several examples of writings in the compilations emphasized that amendments could be extensive but not complete substitutes. Two of these examples involve writings by Alexander Hamilton under the pseudonym of Publius. His first example is from his article in the Independent Journal of New York on December 1, 1787. Hamilton claimed there were "fundamental errors in the structure of the [Confederation]," not "minute or partial imperfections." Hamilton concluded the Confederation (emphasis added) "cannot be amended otherwise than by an alteration in the first principles and main pillars of the fabric." ${ }^{\prime 2}$ His second example is from his article in the New York Packet two weeks later. He said the Confederation (emphasis added) "is ... so radically vicious and unsound, as to admit not of amendment but by an entire change in its leading features and characters." 73 Both of Hamilton's examples stopped short of advocating for a complete substitute to the Articles, as his examples permitted amendments that preserved secondary or minor parts of the Articles.

A third example is from a Columbian Patriot, the pseudonym of Mercy Otis Warren, who published a pamphlet titled Observations on the New Constitution, and on the Federal and State Conventions in 1788. Among other discussions, Warren noted Federalists often argued that states should accept or reject the new constitution in total and without amendments. ${ }^{74}$ She then remarked (emphasis added) "the framers [therefore] dare not risque [sic] to the hazard of revision, amendment, or reconsideration, least the whole superstructure should be demolished by more skilful [sic] and discreet architects." 75 According to Samuel Johnson's dictionary,

70 A Citizen of New Haven [Roger Sherman], The Letters: I-II, New Haven Gazette, 25 December 1788, reprinted in FRIENDS OF THE CONSTITUTION, supra note 41, at 267-68.

71 William Cushing: Undelivered Speech, c. 4 February 1788, reprinted in DocUMENTARY History Digital, supra note 31.

72 The Federalist No. 15 (Alexander Hamilton).

73 The Federalist No. 22 (Alexander Hamilton).

74 See also Pauline Maier, Ratification: The People Debate the Constitution, 1787-1788 50-69 (2010).

75 Observations on the New Constitution, and on the Federal and State Conventions, by A Columbian Patriot, Boston, 1788, reprinted in Documentary History Digital, supra note 31. 
"superstructure" meant "that which is raised or built upon something else."76 Thus, Warren suggested an amendment to the new constitution could have replaced major but not foundational parts of the constitution.

\section{Amendments Could Be Complete Substitutes}

Four examples of ratification records ${ }^{77}$ from the compilations suggested amendments could be complete substitutes, as opposed to the preponderance of evidence that suggested the contrary. The first example is from Aristides' article in the Maryland Gazette on January 31, 1788. Among other assertions, he objected to how the "[Philadelphia] [C]onvention has been censured for an excess of its authority." Aristides first contended the Convention had no power to amend per se and the power only to recommend amendments that the Confederation Congress and states would have to approve. But then Aristides claimed the following (emphasis added):

Had it [the Philadelphia Convention] been even invested with full powers to amend the present compact [Articles], their proposed plan would not have exceeded their trust. Amendment, in parliamentary language, means either addition, or diminution, or striking out the whole, and substituting something in its room. ${ }^{78}$

\section{JOHNSON, supra note 28.}

7 One other record came close to suggesting an amendment to the ARTicles of CONFEDERATION could be a complete substitute. In an article in the Independent Chronicle of Massachusetts on January 3, 1788, Remarker ad corrigendum rebutted the Republican Federalist's criticism from several days earlier in the Massachusetts Centinel that the Philadelphia Convention was supposed to amend and preserve - not abolish-the Articles (see infra Appendix, number 9). Remarker ad corrigendum first remarked that "[e]very article of power, or provision in the former Constitution [the Articles], that was found to be beneficial to our country, is transferred to the new one, under some shape or other[.]" Then, in the following passage, Remarker ad corrigendum further argued the Philadelphia Convention could have nevertheless proposed a complete substitute (emphasis added):

[Even] if there were not a trace of the former [Confederation] existing in it [the new constitution], the Convention could not be charged with having gone beyond their sphere. What do the terms revise, and alter import [referring to the power that the Confederation Congress gave the Philadelphia Convention]? The object of a revision, was to see what parts were unnecessary or defective, and which therefore should be amended. To alter, in consequence of this, was to correct or erase such parts as upon revision, it would be found necessary to do. Can we then, have the least ground for such an imputation [by the Republican Federalist] to [the] Convention? No, my fellow-citizens[.] [See Remarker ad corrigendum, Independent Chronicle, 3 January 1788, reprinted in Documentary History Digital, supra note 31.]

However, Remarker ad corrigendum directly addressed only the meaning of the Convention's power to alter and revise the Articles, which he said permitted complete substitutes. It is unclear if he thought the same for the power to amend the Articles, which he framed as a power that was inherent to-and thus less significant than-the power to alter and revise the Articles.

78 Aristides (Alexander Contee Hanson): Remarks on the Proposed Plan, 31 January 1788, reprinted in Documentary History Digital, supra note 31. 
Aristides thereby suggested only that the definition of amendment according to legislators permitted complete substitutes. He did not suggest "reasonable speakers of English" would have defined amendment in this way. Aristides then warned the public against attempting amendments to the new constitution before its ratification. According to Aristides, there may "never be an end" to amendments, resulting in a complete substitute to the new constitution.

The second example involves a Citizen's article in the Lansingburgh Northern Centinel of New York on January 29, 1788. He responded to the letter that Robert Yates and John Lansing wrote Governor George Clinton after the Philadelphia Convention explaining their opposition to the new constitution. In particular, a Citizen countered Yates' and Lansing's argument that the Philadelphia Convention's amendment power disallowed a complete substitute to the Articles. A Citizen described the amendment power as including the power to completely replace the Articles as follows (emphasis added):

The powers given to the [Philadelphia] Convention were for the purpose of proposing amendments to an old Constitution [the Articles]; one is an old one made new, the other new originally. and [sic] I conceive, with powers so defined, if this body saw the necessity of amending the whole, as well as any of its parts, which they undoubtedly had an equal right to do, thence it follows, that an amendment of every article from the first to the last, inclusive, is such a one as is comprehended within the powers of the Convention, and differs only from an entire new Constitution in this, that the one is an old one made new, the other new originally. ${ }^{79}$

However, a Citizen may have qualified his remarks by saying "I conceive, with powers so defined, [that an amendment can be a complete substitute.]" This possible qualification suggests a Citizen may have thought he was making a novel argument about the scope of an amendment. Therefore, one should not consider this passage to be evidence of how "reasonable speakers of English" in general would have defined the word amendment.

The third example involves Brutus, the pseudonym of Robert Yates, in the New York Journal on April 10, 1788. His article analyzed the implications of each Senate power in the new constitution. When discussing the Senate's amendment power in the Origination Clause, he claimed the Senate "will possess equal powers in all cases with the house of representatives" given this rationale (emphasis added):

[F]or I consider the [Origination] [C]lause which gives the house of representatives the right of originating bills for raising a revenue as merely nominal, seeing the senate are authorised [sic] to propose or concur with amendments." $" 80$

Yates did not explain why he equated the amendment power to the origination power, but his implication appears to be that the amendment power permits complete

\footnotetext{
79 A Citizen, Lansingburgh Northern Centinel, 29 January 1788, reprinted in Documentary History Digital, supra note 31.

80 Brutus XVI, New York Journal, 10 April 1788, reprinted in Documentary History DigiTAL, supra note 31.
} 
substitutes to bills. However, similar to how a Citizen said "I conceive [that an amendment can be a complete substitute]" in the previous example, Yates may have qualified his remarks by saying "I consider" before declaring the amendment power equivalent to the origination power. This possible qualification suggests Yates' understanding of amendment may have been an anomaly. Therefore, one should also not consider this passage to be evidence of what "reasonable speakers of English" in general thought was the meaning of amendment. Regardless, Yates' article broke from his understanding of amendment as something short of a complete substitute expressed months earlier in his letter with Lansing to Governor Clinton.

The fourth example involves Thomas a Kempis' article addressed to "Mr. Russell" in the Massachusetts Centinel on December 29, 1787. Given the precedent of proceedings in the Massachusetts legislature, Kempis made the following observation that the power to amend the Articles may permit such a complete substitute as the new constitution (emphasis added and the original text included all the spelling errors and shorthand):

Mr. RUSSELL, I have seized a moment to inform you, that in my last, haste precluded me from asking the Hon. Mr. ADAMS, or the Hon. Mr. AUSTIN, jun. or some other Candid gentleman, acquainted with Legislative proceedings, whether agreeably to the language of legislation, to case or dele one Act, Resolve, Sec. and to Insert in the room thereof, some other Act, Resolve, Sec. is not called an AMENDMENT? And if it is, whether the erasing or deleing the Old Confederation, and inserting the New Constitution, is not in the language of legislation, a proper AMENDMENT? It was called an amendment when in an Act of the last session, which originated in the Senate, the House, in the appointment of Commissioners on the Western Lands, deled the names of the Governour and two others, and Inserted that of the Hon, James Warren. ${ }^{81}$

However, the inquisitive tone of Kempis' article suggests he thought his observation that amendments might be able to be complete substitutes was unique.

\section{Summary of the Original Public Meaning of Amendment}

According to the definitions of "amendment" and "amend" in the founding-era dictionaries, an amendment is a change or alteration to something that transforms the thing from bad to better. The dictionary definitions suggest an amendment must be germane to what is being amended, as to correct something requires relevant changes. The definitions further suggest an amendment must preserve at least a part of the thing being amended so that there is something to change from bad to better.

Over 60 ratification records representing the views of Federalists and AntiFederalists suggested amendments must be short of complete substitutes. These records ranged from a Native of Virginia's pamphlet suggesting the Senate could not amend a money bill with a "new model" to the Town of Grate Barrington's

81 Thomas a Kempis, Massachusetts Centinel, 29 December 1787, reprinted in DocumenTARY History Digital, supra note 31. 
(Massachusetts) proclamation that the Philadelphia Convention's amendment power disallowed the proposal of a "new form of Fedderial [sic] Government."

Some records implied an amendment had to be germane to the document being amended. For instance, articles about the Origination Clause, such as Brutus' article, suggested any bill amendments would only correct a given bill and thereby be relevant.

Other records suggested an amendment had to preserve at least a minor but significant part of the substance - not the intention or purpose - of the document being amended. My research shows that a "significant part" means a distinct portion that served a function within the document. One such record was Denatus' argument, which said that, if the new constitution had preserved only one article from the Articles of Confederation, then "the objection of innovation would be unreasonable." Article 11 of the Articles stated only that Canada could join the Confederation at any time, ${ }^{82}$ but Denatus evidently would have been satisfied with the preservation of this article.

Several other records indicated an amendment could preserve simply the essence — not the exact language — of the given part. William Cushing's undelivered speech made this point by arguing the new constitution appeared to have kept, among other parts of the Articles, the power to form a navy. The Articles stated the Confederation Congress may "build and equip a navy," 83 whereas the new constitution states the U.S. Congress may "provide and maintain a Navy." ${ }^{\prime 4}$

Four ratification records suggested amendments could be complete substitutes. In one example, Aristides said an amendment can involve "striking out the whole" of a legislative document and "substituting something in its room." In another example, a Citizen claimed the Philadelphia Convention's amendment power permitted the replacement of "the whole" of the Articles.

However, all of these four records suggested only that the view that amendments could be complete substitutes was or may have been the view of at least some legislators or other select individuals, not necessarily "reasonable speakers of English" in general. For example, in his article, Thomas a Kempis made what he perceived to be the unique observation that procedures in the Massachusetts legislature may have permitted amendments to be complete substitutes.

The totality of evidence from the founding-era dictionaries and compilations of ratification records indicates most "reasonable speakers of English" during the founding era would not have been aware of the argument that amendments could be complete substitutes, let alone defined the word amendment as permitting of complete substitutes.

The totality of evidence shows the original public meaning of amendment is a change or alteration to something that must 1) be germane to that something, 2) preserve at least the essence of a significant part of the substance of that something (a "significant part" being a distinct portion that served a function within that something), and 3) make that something transform from bad to better. ${ }^{85}$

\footnotetext{
Articles of Confederation art. XI.

Articles of Confederation art. IX.

U.S. Const. art. I, §8.
}

85 The only other part of the original Constitution that contained the words amend or amendment is Article V, which reads as follows (emphasis added):

The Congress, whenever two thirds of both Houses shall deem it necessary, shall propose Amendments to this Constitution, or, on the Application of the Legislatures of two thirds of the several States, shall call a Convention 


\section{The Original Understanding Of The Scope Of An AMENDMENT}

As discussed in the Introduction, this part rebuts Natelson's claim that the original understanding of the scope of an amendment permits complete substitutes. This part first examines evidence from the British parliament, followed by evidence from the Philadelphia Convention, Confederation Congress, state legislatures, and, lastly, state conventions.

\section{A. BRITISH PARLIAMENT}

My previous research on the Origination Clause examined the practice of the British parliament in the eighteenth century regarding bill amendments. ${ }^{86}$ The research noted that, during the Philadelphia Convention, the drafters of the second half of the Origination Clause borrowed the language verbatim from the Massachusetts Constitution of $1780 .{ }^{87} \mathrm{John}$ Adams, a student of British parliament and philosophy, ${ }^{88}$ drafted the entire Massachusetts Constitution. ${ }^{89}$ According to Professor James McClellan, the U.S. Constitution, based largely on the Massachusetts Constitution, is "rooted in British practices and customs." 90 Thus, the practice of amending bills in British parliament during the eighteenth century is particularly relevant to discussions of the original understanding of the scope of an amendment. But, as Natelson's article discussed, it is worth noting the British parliament's records from this time period have limitations, including being incomplete and biased toward the viewpoints of legislators who distributed their written speeches. ${ }^{91}$

\footnotetext{
for proposing Amendments, which, in either Case, shall be valid to all Intents and Purposes, as Part of this Constitution, when ratified by the Legislatures of three fourths of the several States, or by Conventions in three fourths thereof, as the one or the other Mode of Ratification may be proposed by the Congress; Provided that no Amendment which may be made prior to the Year One thousand eight hundred and eight shall in any Manner affect the first and fourth Clauses in the Ninth Section of the first Article; and that no State, without its Consent, shall be deprived of its equal Suffrage in the Senate. [See U.S. Const. art. V.]
}

The original public meaning of amendment also applies to Article V. Thus, any amendment to the Constitution must 1) be germane to the Constitution, 2) preserve at least the essence of a significant part of the substance of the Constitution, and 3) make the Constitution transform from bad to better.

86 Daniel Smyth, The Origination Clause III: ObamaCare's a Good Amendment to Die Hard (November 29, 2013), available at http://www.americanthinker.com/articles/2013/11/ the_origination_clause_iii_obamacares_a_good_amendment_to_die_hard.html.

872 The Records Of The Federal Convention OF 1787552 (Max Farrand ed., 1937) [hereinafter FARRAND's RECORDS].

88 James Mcclellan, Liberty, Order, and Justice: An Introduction to the Constitutional Principles of American Government 49-50 (3D ed., 2000) [hereinafter Mcclellan, LibERTY, ORDER, AND JUSTICE].

89 Robert J. Taylor, Construction of the Massachusetts Constitution, 90 PROC. AM. ANTIQ. SOC. 326 (1980).

90 MCClellan, Liberty, Order, and Justice, SUPRA NOte 88, at 25.

91 Natelson, Origination Clause, supra note 1, at 646, n.60. 


\section{Amendments Could Not Be Complete Substitutes}

Natelson's article confirmed much of my previous research, which argued the British parliament most likely disallowed amendments that were complete substitutes. Natelson examined the years 1740 through 1790, and he analyzed many sources, such as the official journals of the House of Commons and House of Lords. ${ }^{92}$ My previous research examined the 23 volumes of Cobbett's Parliamentary History of England that cover 1688 to 1789 , the century before the founding..$^{93}$ Although not published until the nineteenth century, Cobbett's Parliamentary History is the best source of parliamentary debates between 1066 and 1803. ${ }^{94}$ Cobbett compiled multiple records of British parliament, including parts of the journals of the Lords and Commons and newspaper accounts of legislators' speeches. In the 23 volumes, I searched for occurrences of amend and words with the root of amend. I found no examples of bill amendments that were complete substitutes. In fact, three passages from debates on various bills declared or suggested that parliamentary procedure prohibited such amendments.

The most revealing example occurred in 1736 when the Lords received the Commons" "Bill for the more easy recovery of the Tythes, Church Rates, and other Ecclesiastical Dues, from the people called Quakers." After the second reading of this bill by the Lords and in the context of proposing amendments to the bill, a lord whose name the Parliamentary History does not mention said the following to oppose the bill:

I think it impossible to make a proper Bill of that we have now before us, without altering the whole, which, according to our methods of proceeding, cannot be done in the committee; for as the Bill would then be a new Bill, it could not be pretended that such a Bill had been twice read, then committed, and after that read a third time, which is the method of passing Bills constantly observed in this House.

Other lords who debated this Quaker bill agreed with the above assessment. For example, one lord proposed an amendment that would "be but a small and an easy amendment to the Bill; it will be very far from making it a new Bill." ${ }^{95}$

Id.

93 William Cobbett, The Parliamentary History of England (vols. 5-27, 1809-16) [hereinafter Совветт]. My article does not discuss John Hatsell's four-volume work titled Precedents of Proceedings in the House of Commons. This work was the most prominent publication on parliamentary procedures in the late 1700s. However, none of his volumes discussed procedures for originating, passing, or amending bills that are relevant to my article. His topics included "Privilege of Parliament" (1776), "Members, Speakers, \&c." (1781), "Relating to Lords, and Supply" (1784), and "Conference, and Impeachment" (1796). Hatsell intended to write a volume about the passing of bills, but he never published this work. See Sheila Lambert, Bills And Acts: Legislative Procedure in EighteEnTH-Century England 28 (1971).

94 "Records Frequently Asked Questions," Parliament of the United Kingdom, available at http://www.parliament.uk/business/publications/parliamentary-archives/archives-faqs/ records-frequently-asked-questions/\#jump-link-10.

959 Совветт, supra note 93, at 1165-66, 1179, 1196, 1207. 
A second example is from 1743 when the Lords debated the Commons' bill "For repealing certain Duties on Spirituous Liquors, and on Licences for retailing the same; and for laying other Duties on Spirituous Liquors, and on Licences for retailing the said Liquors." The Earl of Ilay declared his fellow lords should consider the bill as follows (emphasis added):

If it be a Bill your lordships think essentially wrong, or such a one as cannot be amended so as to make it a useful Bill, you reject it upon a second reading: if it be a Bill which you think may be amended, so as to make it a good bill, you go through it in the committee, and if after having there made all the amendments you can, it appears still to be a defective or inconvenient Bill, you throw it out upon the report, or upon the third reading.

Thereby, the earl said the Lords could amend the Commons' bill to make it "useful" or "good," but not to make it a different bill. ${ }^{96}$

The third example was in 1719 when the Commons considered the Lords' "Act for the Settling [sic] 'the Peerage of Great Britain." Sir Richard Steele said this (emphasis added) "unreasonable Bill will be entirely rejected, since none can pretend to amend what is in its very nature incorrigible ... it would be in vain to attempt a good superstructure, upon a foundation which deserves nothing but indignation and contempt." If the Commons could amend the Lords' "unreasonable Bill" by completely replacing it with a "different and reasonable Bill," then surely Steele would have said the Commons could do so. The Commons rejected the bill. ${ }^{97}$

\section{Amendments Could Be Extensive}

According to the Parliamentary History, there were several examples of amendments that involved replacements to or modifications of many or most parts of the given bills. For example, in 1692, the Lords made "very many amendments" to the Commons' "Bill for regulating Trials, in cases of Treason." The Commons "agreed

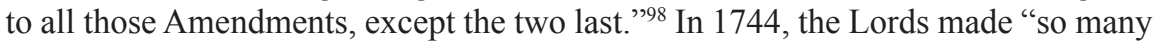
alterations" to the Commons" "Bill for making it Treason to hold Correspondence with the Sons of the Pretender to his majesty's crown" that "[the bill's] original intention ... [was] almost forgotten." The Lords even amended the bill's title, and the Commons agreed to all the Lords' amendments. ${ }^{99}$ And in 1753, Mr. William Beckford of the Commons said the following after the Commons "almost entirely altered" the Lords" "Bill for the better preventing of Clandestine Marriages":

[W] hat may constitute a Bill to be the same or a new Bill, is a question that may admit of some disputes, and a question, I think, not very material; but if seven new clauses added to a Bill which at first consisted but of sixteen, and every one of those it consisted of at first very much altered, does not

\footnotetext{
12 CoBBetT, supra note 93 , at 1191, 1246, 1247.

7 Совветт, supra note 93, at 609, 615-16, 624.

5 Cовветт, supra note 93, at 691-92.

13 Cовветт, supra note 93, at 705, 806, 858-59, 895.
} 
make it a new Bill, I am sure, it shews [sic], that the Bill, as sent down to us [from the Lords], was a very inconsiderate and imperfect Bill[.]

The Lords agreed to all the Commons' amendments to this marriage bill. ${ }^{100}$

\section{Summary of British Parliament}

The British parliament's records from the eighteenth century are incomplete and have other limitations. Nevertheless, according to available sources, it is evident that, at least for the several decades before the founding, the British parliament prohibited bill amendments from being complete substitutes. The parliament permitted extensive amendments to bills, but extensive amendments could not amount to originations of new bills.

\section{B. PhILAdELPHIA CONVENTION}

On May 25, 1787, the Philadelphia Convention began with what many framers had understood to be the purpose of amending the Articles of Confederation. ${ }^{101}$ Leading up to the Convention, many national leaders, such as James Madison, advocated for amending the Articles by giving the Confederation Congress more powers, including the power to regulate interstate trade. ${ }^{102}$ However, on May 29, Edmund Randolph of Virginia proposed the Virginia Plan, a collection of major amendments to the Confederation's structure that would have, among other changes, added an executive, a judiciary, and a bicameral legislature to the Confederation. ${ }^{103}$ Discussion of this plan and rival plans dominated most of the Convention. Throughout much of the spring and summer, the Convention approved the Virginia Plan piecemeal and made many amendments to this plan's provisions. For instance, on May 31, the Convention approved a resolution creating a bicameral legislature. ${ }^{104}$ On June 4, the Convention approved a resolution establishing a national judiciary, ${ }^{105}$ which the Convention amended on June 13 by adding a provision empowering the Senate to appoint the judiciary. ${ }^{106}$

In late July, the Convention finished approving and amending the Virginia Plan, which amounted to 19 resolutions for having an effective government. ${ }^{107}$ However, the Convention, instead of recommending that the Confederation Congress and states adopt the resolutions as amendments to the Articles, formed the Committee of Detail to draft a new constitution based on the resolutions. ${ }^{108}$ On August 6, the committee proposed a draft of the new constitution, which was three times as long

10015 COBBEтT, supra note 93 , at 1, 32, 69, 86.

101 See supra note 14.

102 See, e.g., Rakove, Collapse, supra note 15, at 232.

103 1 FARRAND's ReCORDS, supra note 87, at 19-20 (Madison, May 29, 1787).

104 Id. at 48 (Madison, Thursday May 31).

105 Id. at 104-05 (Madison Monday June 4. In Committee of the whole).

1065 The Debates in the Several State Conventions on the Adoption of the Federal Constitution 188 (Jonathan Elliot ed., Washington, 2d ed. 1836) [hereinafter Elliot's Debates].

107 David O. Stewart, The Summer of 1787: The Men Who Invented the Constitution 178 (2007) [hereinafter STEWART, SUMMER].

108 See, e.g., 2 Farrand's ReCords, supra note 87, at 88-96 (MADISON Monday. July. 23. in Convention). 
as the 19 resolutions and which added numerous provisions not approved by the Convention, to replace the Articles. ${ }^{109}$ Between that day and September 17, the Convention revised the draft. On September 17, the Convention approved and then sent the new constitution to the Confederation Congress for consideration. ${ }^{110}$

\section{Natelson's Evidence}

The only substantive evidence Natelson found regarding the framers' views concerning the scope of an amendment was comments by James Madison, a Federalist and perhaps the Convention's most influential participant. On August 13, 1787, the framers had been discussing the following draft of the Origination Clause (emphasis added):

Bills for raising money for the purpose of revenue or for appropriating the same shall originate in the House of Representatives and shall not be so amended or altered by the Senate as to increase or diminish the sum to be raised, or change the mode of levying it, or the object of its appropriation. ${ }^{111}$

And then Madison commented as follows (emphasis added):

The words amend or alter, form an equal source of doubt \& altercation. When an obnoxious paragraph shall be sent down from the Senate to the House of Reps it will be called an origination under the name of an amendment. The Senate may actually couch extraneous matter under that name. In these cases, the question will turn on the degree of connection between the matter \& object of the bill and the alteration or amendment offered to it. Can there be a more fruitful source of dispute, or a kind of dispute more difficult to be settled? ${ }^{112}$

Natelson argued Madison meant a bill amendment can be "very broad" but must address the bill's subject matter and object. ${ }^{113}$ Thereby, Natelson implied Madison's comments fit into Natelson's larger narrative that amendments must be germane and can completely replace legislation.

However, Madison did not, as Natelson implied, say simply that an amendment must have a "degree of connection" with the bill's "matter \& object." Madison said only that the answer to whether a bill amendment is acceptable requires an examination of the amendment's "degree of connection" with the bill's "matter \& object." Madison did not specify the "degree of connection," which could be low or higher. Since a higher "degree of connection" could require the amendment to preserve a part(s) of the substance of the original bill, it is unclear from Madison's comments if he would accept a complete substitute to a bill.

109 SteWART, Summer, supra note 107, at 178-180.

110 The Confederation Congress and the Constitution, 26-28 September 1787, reprinted in Documentary History Digital, supra note 31.

1112 FARRAND's RECORDS, supra note 87, at 273 (Madison, Aug. 13, 1787).

$112 \quad$ Id. at 276.

113 Natelson, Origination Clause, supra note 1, at 705. 


\section{My Evidence}

The Convention's most significant discussions of the scope of an amendment concerned the Articles of Confederation and not the Origination Clause. Article 13 of the Articles, which allowed alterations to the Articles, read in part as follows (emphasis added):

[T] he Articles of this Confederation shall be inviolably observed by every State, and the Union shall be perpetual; nor shall any alteration at any time hereafter be made in any of them; unless such alteration be agreed to in a Congress of the United States, and be afterwards confirmed by the legislatures of every State. ${ }^{114}$

And on February 21, 1787, the Confederation Congress had given the Philadelphia Convention this mission (emphasis added):

[To meet] for the sole and express purpose of revising the Articles of Confederation and reporting to Congress and the several legislatures such alterations and provisions therein as shall ... render the federal constitution adequate to the exigencies of Government and the preservation of the Union. ${ }^{115}$

Of course, Article 13 and the Philadelphia Convention's mission stated the Confederation Congress and states could alter or revise the Articles. The word amend was not used. However, as indicated in the Introduction, the founders often used the words alter and amend as synonyms and several founding-era dictionaries actually defined an amendment as a type of alteration that corrects something. Thus, many framers discussed either explicitly or implicitly whether the Convention's amendment power permitted the proposal of a new constitution.

I searched Farrand's Records, ${ }^{116}$ the primary source of the Convention's records, for occurrences of amend and words with the root of amend near the words Articles of Confederation. I found the following relevant records.

\section{a. Amendments Could Not Be Complete Substitutes}

Numerous records from the Convention suggest an amendment to the Articles could not be a complete substitute. On May 30, 1787, a day after Randolph proposed the Virginia Plan, someone proposed two resolutions that essentially said the Confederation could never be amended properly. For instance, the first resolution stated "[ $t]$ hat a union of the states, merely federal [i.e., the Confederation], will not accomplish the objects proposed by the Articles of Confederation, namely, common defence, security of liberty, and general welfare." A third resolution was also proposed that recommended the establishment of a national government featuring a supreme judiciary, legislature, and executive. Thus, together these three resolutions suggested the Convention should forget about amending the Confederation and

114 Articles of CONFEDERATION art. XIII.

1153 FARRAND's RECORDS, supra note 87, at 14.

116 FARRAND's RECORDS, supra note 87. 
replace it with a new system of government. However, Charles Pinckney of South Carolina, evidently shocked at the first resolution in particular, objected to proposing new systems of government to replace the Confederation as follows:

[I]t appeared to him [Pinckney] that their [the framers'] business was at an end; for as the powers of the house in general were to revise the present confederation, and to alter or amend it as the case might require; to determine its ... incapability of amendment or improvement, must end in the dissolution of the powers.

Convention notes stated " $[t]$ his remark had its weight, and in consequence of it" the framers withdrew the two resolutions suggesting the Confederation could never be amended properly. ${ }^{117}$ If the framers had thought an amendment to the Articles could be a complete substitute, then the framers would have resolved that an amendment to the Articles could be a new system of government.

On June 9, a committee of the whole house discussed the Virginia Plan's rules for voting for the national executive. ${ }^{118}$ Anti-Federalist Elbridge Gerry of Massachusetts then proposed amending the plan to give higher-populated states greater influence than lower-populated states in electing the executive. William Paterson of New Jersey, however, renounced Gerry's proposal and any future amendment that might erode state equality in the Confederation as follows:

$[\mathrm{T}]$ he amendment of the confederacy was the object of all the laws and commissions on the subject ... the articles of the confederation ... [should] therefore [be] the proper basis of all the proceedings of the Convention. We ought to keep within its limits, or we should be charged by our constituents with usurpation. that [sic] the people of America were sharpsighted and not to be deceived. But the Commissions under which we acted were not only the measure of our power. they [sic] denoted also the sentiments of the States on the subject of our deliberation. The idea of a national Govt. [sic] as contradistinguished from a federal one, never entered into the mind of any of them, and to the public mind we must accommodate ourselves. We have no power to go beyond the federal scheme [the Confederation.] ${ }^{119}$

In particular, Paterson's comment that "[w]e have no power to go beyond the federal scheme [the Confederation]" suggested any amendment to the Articles could not fully replace the Confederation and had to preserve at least the Confederation's essential qualities.

On June 16, John Lansing of New York made a comment similar to Paterson's. The committee of the whole house was considering whether to scrap the Virginia Plan for the New Jersey Plan, ${ }^{120}$ a plan proposed a day earlier. The New Jersey Plan was less ambitious than the Virginia Plan, and the New Jersey Plan proposed such changes to the Articles as an allowance for the Confederation Congress to

117 FARRAND's RECORDS, supra note 87, at 38-39.

118 Id. at $175-76$.

119 Id. at $177-78$.

120 Id. at 249. 
regulate interstate commerce. ${ }^{121}$ Preferring the New Jersey Plan, Lansing criticized the Virginia Plan as exceeding the Convention's powers. Lansing declared that "the power of the Convention was restrained to amendments of a federal nature, having for their basis the Confederacy in being." 122

On June 18, Alexander Hamilton of New York acknowledged the Virginia Plan may violate the Convention's amendment power because the plan drastically reduced the role of states, making "the people" the national government's ultimate source of power. ${ }^{123}$ However, Hamilton justified any possible violation as follows (emphasis added):

\begin{abstract}
$[W]$ e ow [e] it to our Country, to do on this emergency whatever we should deem essential to its happiness. The States sent us here to provide for the exigences [sic] of the Union. To rely on \& propose any plan not adequate to these exigences, merely because it was not clearly within our powers, would be to sacrifice the means to the end. It may be said that the States can not ratify a plan not within the purview of the article of Confederation providing for alterations \& amendments. But may not the States themselves in which no constitutional authority equal to this purpose exists in the Legislatures, have had in view a reference to the people at large. ${ }^{124}$
\end{abstract}

Thereby, Hamilton said an amendment to the Articles may have to preserve at least the essential quality of the Articles wherein states are the ultimate source of the national government's power. Of course, this argument appears more close-minded than Hamilton's arguments as Publius, discussed earlier, that suggested a valid amendment could preserve only secondary or minor parts of the Articles. Even so, all his arguments suggested amendments should be short of complete substitutes. Hamilton's invocation of the "country's happiness" as part of the justification for the possible violation by the Virginia Plan of the Convention's amendment power most likely made reference to Salus Populi est suprema Lex, which was the legal principle in the founding era that the welfare of the people is the supreme law. ${ }^{125}$

On June 30, Gunning Bedford, Jr., of Delaware discussed how lower-populated states could never accept the Virginia Plan, as it would give higher-populated states greater power in a national government. ${ }^{126}$ After all, Article V of the Articles of Confederation stated, in part, that "[i]n determining questions in ... Congress ... each State shall have one vote." 127 And, one day earlier, the Convention had affirmed the part of the Virginia Plan that gave states proportional representation in the lower house of the national legislature. ${ }^{128}$ Bedford claimed the empowerment of higher-populated states by the Virginia Plan would destroy the Confederation's

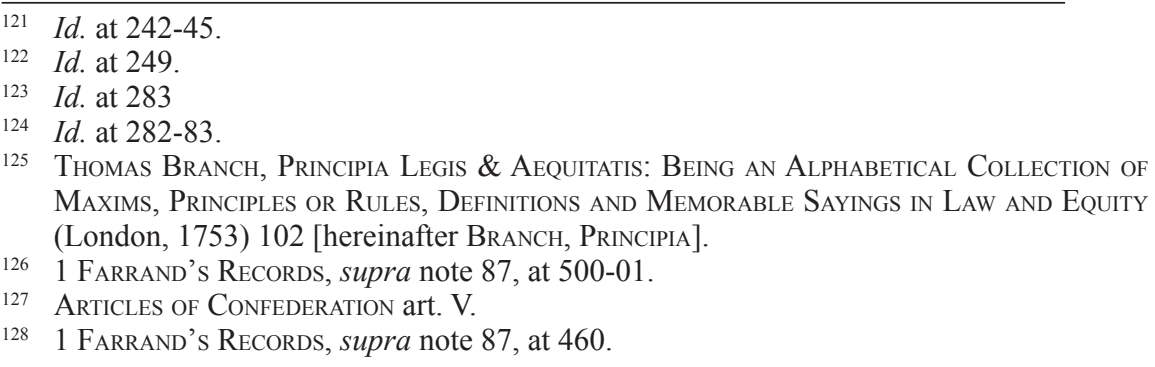

1281 FARRAND's RECORDS, supra note 87, at 460. 
essence of having state equality in national affairs. Bedford further argued "[1]et us then do what is in our power-amend and enlarge the confederation, but not alter the federal system. The people expect this, and no more." 129 By saying "not alter the federal system," Bedford most likely meant "not destroy the confederation's essential qualities, particularly state equality under a national government." Bedford thus believed no amendment to the Articles could replace all of the Confederation.

\section{b. Amendments Could Be Extensive}

Several Convention passages suggest an amendment could be extensive but not a complete substitute. The following example occurred on June 16 when Governor Randolph responded to criticism that his Virginia Plan destroyed state equality:

It has been contended that the 5th article of the confederation [state equality] cannot be repealed under the powers to new modify the confederation by the 13th article. This surely is false reasoning, since the whole of the confederation upon revision is subject to amendment and alteration[.] $]^{130}$

Thus, Randolph said no part of the Articles was untouchable but stopped short of approving complete substitutes.

A second example occurred on June 19 when someone again claimed the Virginia Plan violated state equality. ${ }^{131}$ Rufus King of Massachusetts responded by echoing the essence of Randolph's above idea as follows (the original text included all the shorthand):

The Convention could clearly deliberate on \& propose any alterations that Congs. could have done under ye. federal articles. and could not Congs. propose by virtue of the last article [Article 13], a change in any article whatever: And as well that relating to the equality of suffrage, as any other. ${ }^{132}$

King thereby emphasized that any given part of the Articles could be altered, but he did not declare an alteration could completely replace the Articles.

In another example from June 19, James Wilson of Pennsylvania, while discussing the controversy over state equality in the Virginia Plan, explained what he believed was the limit of the scope of the Convention's alteration power. "[E] very article may be totally altered," he said, "except that wh[ich] destroys the Idea of a confedy [confederation]." Although Wilson did not identify the article(s) in the Articles of Confederation without which there would be no confederation, he said an extensive alteration must leave "to each State the right of regulating its private $\&$ internal affairs in the manner of a subordinate corporation[.]"133 Article II of the Articles read, "[e]ach state retains its sovereignty, freedom, and independence, and

\footnotetext{
Id. at 501-02.

Id. at 262.

1 FARRAND's RECORDS, supra note 87, at 324.

Id. at 324 .

Id. at 332 .
} 
every power, jurisdiction, and right, which is not by this Confederation expressly delegated to the United States, in Congress assembled." 134 Perhaps Wilson meant alterations to the Articles must preserve this article or include a similarly-worded one. Regardless, Wilson's comments suggest any alteration to the Articles could not be a complete substitute and had to preserve at least the Confederation's essence.

\section{Summary of the Philadelphia Convention}

Natelson's article presented no actual evidence from the Philadelphia Convention that the framers believed amendments could be complete substitutes. Natelson incorrectly implied that James Madison's comments regarding the Senate's amendment power in a draft of the Origination Clause demonstrated Madison approved of complete but germane substitutes to bills.

My article found no evidence from the Convention that suggested an amendment to the Articles of Confederation could be a complete substitute. Even Federalists never connected the proposal of the new constitution to the Convention's amendment power. Alexander Hamilton's comments regarding the Virginia Plan suggested Salus Populi could have authorized the proposal of the new constitution. Much evidence, such as comments by Pinckney, Paterson, and Bedford, suggested amendments to the Articles could not be complete substitutes. Other evidence, including comments by Randolph, King, and Wilson, suggested amendments could be extensive but not complete substitutes.

\section{Confederation Congress}

On September 20, 1787, the Confederation Congress received the Philadelphia Convention's new constitution to consider relaying to state legislatures. Between September 26 and 28, Congress discussed the new constitution's propriety. ${ }^{135}$ I searched The Documentary History of the Ratification of the Constitution, which contains notes from these days in Congress, for occurrences of amend and words with the root of amend near the word confederation or other words with the root of "confed." I found the following two relevant records from September 27. ${ }^{136}$

\section{Amendments Could Not Be Complete Substitutes}

The first record was the proposed resolution by Anti-Federalist Richard Henry (R.H.) Lee that stated, in part (emphasis added), "the said Constitution [i.e., the Articles of Confederation] in the thirteenth article thereof limits the power of Congress to the amendment of the present Confederacy ... but does not extend it to the creation of a new confederacy[.]" According to this resolution, R.H. Lee thought the new constitution was a complete substitute to the Articles and thus not an amendment.

134 Articles of Confederation art. II.

135 The Confederation Congress and the Constitution, 26-28 September 1787, reprinted in Documentary History Digital, supra note 31.

136 Natelson's search of the official journals of the Continental Congress and Confederation Congress found no evidence that suggested the congresses permitted amendments that were complete substitutes. See Natelson, Origination Clause, supra note 1, at 681-82, 687. 
Nevertheless, out of respect for the framers' efforts, his resolution asked Congress to relay the new constitution to state legislatures. ${ }^{137}$

The second record was notes by Delegate Melancton Smith. According to these notes, R.H. Lee's resolution instigated an interesting discussion about the new constitution's legal authority between Federalist Henry Lee, James Madison, Federalist William Samuel (W.S.) Johnson, and others. Henry Lee responded to R.H. Lee's resolution by saying "we [Congress] have a right to decide [the new constitution's fate] from the great principle of necessity or the [principle of] salus populi. This necessity justifies the measure." The founders knew the principle of necessity in Latin as Necessitas est lex temporis. ${ }^{138}$ So, Henry Lee suggested the Confederation Congress would not exceed its power if it proposed the new constitution to state legislatures because Congress could invoke Salus Populi or Necessitas. ${ }^{139}$

James Madison likewise opposed the part of R.H. Lee's resolution that claimed Congress was exceeding its power. Madison argued Congress could invoke Salus Populi as it had done several other times. One example he gave was in 1784 when Congress began establishing state governments in territory west of the 13 states. ${ }^{140}$ Madison repeated this Salus Populi argument in his letter to General George Washington on September 30, 1787. This letter further detailed Madison's objections to R.H. Lee's resolution. ${ }^{141}$ Of course, Madison's argument in Congress was different from his argument as Publius, discussed earlier, that said the new constitution was an extensive alteration to the Articles. Nevertheless, both arguments suggested an amendment could not be a complete substitute.

W.S. Johnson opposed R.H. Lee's resolution because it could make " $[t]$ he people ... see [that] we, that Congress, act without power[.]" However, W.S. Johnson also suggested Congress' legal authority could be Salus Populi. He concluded Congress should simply "approve or disapprove" the new constitution and not attempt to bias state legislatures against the new constitution. ${ }^{142}$

After this exchange about the new constitution's legal authority, Congress postponed and thereby effectively defeated R.H. Lee's resolution. ${ }^{143}$

\section{Summary of the Confederation Congress}

This exchange suggests the delegates who debated R.H. Lee's resolution, whether Federalist or Anti-Federalist, thought the new constitution was a complete substitute to the Articles and thus not an amendment. Of course, R.H. Lee made this very argument in his resolution. But also, Henry Lee, James Madison, and W.S. Johnson

137 Richard Henry Lee's Motion, Journals of Congress, 27 September, reprinted in DocuMENTARY History Digital, supra note 31.

138 Branch, PrinciPia, supra note 125, at 63.

139 Melancton Smith's Notes, 27 September [I], reprinted in Documentary History DigiTAL, supra note 31 .

140 Id.

141 James Madison to George Washington, Sepr. [sic] 30. 1787, reprinted in 24 LetTers OF Delegates To Congress, 1774-1789 457 (Paul H. Smith et al., eds., 1976-2000).

142 Melancton Smith's Notes, 27 September [I], reprinted in Documentary History DigiTAL, supra note 31 .

143 Melancton Smith's Notes, 27 September [II], reprinted in Documentary History DigiTAL, supra note 31. 
suggested the legal authority of the Philadelphia Convention and Confederation Congress to propose a new constitution was Salus Populi or Necessitas and not the amendment power.

\section{STATE LEGISLATURES}

On September 28, 1787, the Confederation Congress relayed the new constitution to state legislatures, which would decide upon having state conventions that would consider ratification. ${ }^{144}$ That day and despite having yet to receive official word of the approval by the Confederation Congress of the new constitution, the Pennsylvania legislature became the first to call for a convention. By the end of 1787, all of the 13 states in the Confederation had called for a convention except for South Carolina, New York, and Rhode Island. Over two years later in January 1790, Rhode Island became the last of the 13 states to call for a convention. ${ }^{145}$

\section{Natelson's Evidence}

To determine if any state legislatures had permitted amendments that were complete substitutes in the decades leading up to the founding, Natelson examined the legislatures' available records, such as official journals, from this time period. Natelson said he found examples of complete substitutes in the legislatures of Virginia, North Carolina, New Jersey, Pennsylvania, and Massachusetts. ${ }^{146}$ However, Natelson correctly identified complete substitutes in only the Virginia legislature. As he documented, in 1780, two resolutions in the Virginia legislature involved complete substitutes. In the first example, the committee of the whole house reported a resolution calling for a tax "for the use of the continent" and new funds to reduce state debt and help with the Revolutionary War. The complete substitute stated Virginia should seek funding from the Continental Congress before issuing any new taxes. ${ }^{147}$ In the second example, a proposed resolution stated Meriwether Smith, who represented Virginia in the Continental Congress, was guilty of abusing public money and should be recalled from service. The complete substitute declared only that Smith's use of public money "appear[s] to be unsatisfactory" and that he should settle any discrepancies. ${ }^{148}$

Natelson's examples of complete substitutes from the legislatures of New Jersey, North Carolina, Pennsylvania, and Massachusetts were examples of only extensive amendments to resolutions or bills. Natelson's example from New Jersey was in 1780 and involved the following resolution (emphasis added):

That it is the Opinion of this Committee, that the Act for the Limitation of Prices, and to prevent the with-holding the Necessaries of Life from Sale,

\footnotetext{
14433 Journals of the Continental Congress, 1774-1789 548-49 (Worthington C. Ford et al. eds, 1904-37) (Friday, September 28, 1787).

145 Gregory E. Maggs, A Concise Guide to the Records of the State Ratifying Conventions as a Source of the Original Meaning of the U.S. Constitution 2009 (2) U. ILL. L. REV. 467-68 (2009) [hereinafter Maggs, Concise Guide].

146 Natelson, Origination Clause, supra note 1, at 682-86

147 Id. at 682, n.247.

$148 \quad I d$. at 683.
} 
already agreed to be gone into at this Sitting, will be sufficient to enable the Purchasers for the Army to procure all the Flour which this State will be able to furnish.

Someone proposed an amendment that replaced the resolution except for the line, "will be sufficient to enable the Purchasers for the Army to procure all the Flour which this State will be able to furnish." ${ }^{149}$ So, as the amendment kept the original resolution's directive to get purchasers for the Army enough flour for the state to furnish, the amendment was not a complete substitute.

Natelson's example from North Carolina occurred in 1777 when someone proposed an amendment to the following resolution (emphasis added):

This House have resolved that the Treasurers of this State be allowed after the rate of five hundred pounds each per annum during their continuance in office for the ensuing year in lieu and satisfaction of all services as Treasurers.

The amendment read as follows (emphasis added):

Resolved that the two Treasurers of this State hereafter chosen be allowed the sum of five hundred pounds each per annum for the ensuing year, in lieu and satisfaction of all services as Treasurers. ${ }^{150}$

The amendment avoided being a complete substitute by keeping the original resolution's stipulation that "Treasures of this State ... be allowed" a certain payment "for the ensuing year ... in lieu and satisfaction of all services as Treasurers."

Natelson's example from Pennsylvania involved a resolution in 1785 that called for "the appointment of a committee "to bring in a bill directing the commissioners of the city and several counties in this state' to make out an assessment roll." According to Natelson, someone completely replaced this resolution by proposing "[that] the assessment roll ... [instead] be prepared "by each county within this state" along with some "technical changes." ${ }^{151}$ However, these amendments avoided completely replacing the resolution because the amendments kept the original resolution's overall directive that the legislature should appoint a committee to propose a bill that would direct state officials to make an assessment roll.

Regarding the Massachusetts legislature, Natelson noted there are few available records. He analyzed only one volume of journals, which was from 1784. This volume noted the senate so "[h] eavily amended" many of the house's money bills that the house had to write the original bills as "new draft[s]." Natelson suggested these new drafts must have amounted to complete substitutes. However, Natelson thereby assumed the new drafts excluded significant provisions from the original bills. Just because a bill became a "new draft" after extensive amendments does not mean "all the language in ... [that] bill ... after the enacting clause ... was removed and replaced with new language." 152 Accordingly, Natelson's evidence from

\footnotetext{
49 Id. at 683-84.

$150 \quad I d$. at 684.

151 Id. at 685-86.

152 Id. at 686.
} 
Massachusetts shows only that the legislature permitted extensive amendments to bills.

\section{My Evidence}

There is significant evidence regarding the original understanding of the scope of an amendment from debates in state legislatures about the new constitution. I searched The Documentary History of the Ratification of the Constitution, the primary source of these debates, for occurrences of amend and words with the root of amend near the word confederation or other words with the root of "confed." I also examined Farrand's Records, which contains some speeches given during these debates. I found the following relevant records from the legislatures of Pennsylvania, New York, and Maryland.

\section{a. Pennsylvania Legislature}

As mentioned earlier, on September 28, 1787, and without having received word of the approval by the Confederation Congress of the new constitution, the House of Representatives of Pennsylvania began debating the propriety of calling for a state convention that would consider ratifying the new constitution. Anti-Federalists Robert Whitehill and William Findley asked the House to await the official paperwork from Congress before proceeding. These assemblymen claimed the new constitution was an alteration to the Articles of Confederation because the framers were "limited to act federally ... [and] acted federally" and the new constitution was on "federal ground." By saying the new constitution was on "federal ground," Whitehill and Findley most likely meant the constitution formed a government system in which states maintain independence from a national government. According to Whitehill and Findley, as the new constitution altered the Articles, Pennsylvania had to follow the rules for altering the Articles in Article 13, including the rule that the Confederation Congress must approve any alterations before state legislatures do so. ${ }^{153}$ Thereby, both assemblymen implied the new constitution was not a complete substitute to the Articles because the new constitution preserved some essential aspects of the Confederation.

Several Federalists opposed Whitehill's and Findley's argument, claiming Pennsylvania could approve the new constitution before the Confederation Congress. These assemblymen said that, because the new constitution was not an alteration or amendment to the Articles, no states should follow Article 13. For instance, Assemblyman William Robinson said the new constitution was "new ground," "a different organization [than the Articles]," and "no alteration of any particular article of the Confederation, which is the only thing provided for." Robinson added the Convention "did not think of amending and altering the present Confederation, for they saw the impropriety of vesting one body of men [the Confederation Congress] with the necessary powers." Assemblyman Thomas Fitzsimmons asked Findley if he "ever looked at the new Constitution? If he has, he will see it is not an alteration of an article in the old, but that it departs in every principle from the other." Fitzsimmons further said the framers "found the Confederation ... so decayed that it was impossible to graft a useful article upon it." Assemblyman Hugh

153 Assembly Debates, A.M., reprinted in Documentary History Digital, supra note 31. 
Brackenridge added the new constitution was "not on federal ground but on the wild and extended field of nature, unrestrained by any former compact[.]"154 In other words, a new social contract in the form of the new constitution should not be restrained by rules from the Articles.

Despite these differences between Whitehill's and Findley's argument and the other assemblymen's arguments about whether the new constitution altered or amended the Articles, all the assemblymen agreed an alteration or amendment could not be a complete substitute. For Whitehill and Findley, if the new constitution had not, in their opinion, preserved aspects of the Confederation that maintained state independence from a national government, then the new constitution would not have qualified as an alteration to the Articles. For the other assemblymen, such as Robinson, if the new constitution contained at least one alteration of "any particular article of the Confederation," then the new constitution could have qualified as an alteration or amendment to the Articles.

Interestingly, a few days after making their above arguments, Whitehill and Findley signed "The Address of the [Sixteen] Seceding Assemblymen," mentioned earlier, in which 16 legislators from Pennsylvania described their opposition to the new constitution. ${ }^{155}$ This address said that, instead of "amend[ing] ... the present Confederation," the Convention "annihilate[d] the ... Confederation and form[ed] a constitution entirely new[.]" 156 Thus, Whitehill and Findley evidently changed their minds about whether the new constitution altered the Articles.

It appears Whitehill's and Findley's original argument that the new constitution altered or amended the Articles was only a delay tactic. These assemblymen were probably trying to delay a vote regarding the new constitution so they would have time to convince other assemblymen to oppose the new constitution. Historians have noted that, after the Philadelphia Convention proposed the new constitution, Federalists in Pennsylvania rushed to ratify the constitution while Anti-Federalists scrambled to prevent a blitzkrieg. ${ }^{157}$

\section{b. New York Legislature}

On January 31, 1788, the New York State Assembly debated a resolution that stated a state convention should consider ratifying the new constitution. Representative Cornelius Schoonmaker wanted to amend the resolution by adding, among other statements, that "[the] Convention ... instead of revising and reporting alterations and provisions in the Articles of Confederation, have reported a new Constitution for the United States[.]" ${ }^{158}$ Representative Samuel Jones agreed with Schoonmaker, saying "ought we not ... inform the people [about] the grounds on which the Convention have proceeded? That they had gone beyond their powers, and instead of amending the Confederation, had framed a new Constitution." Other representatives, such as Egbert Benson and Richard Harison, claimed Schoonmaker's amendment

154 Id.

1553 Complete Anti-Federalist, supra note 32, at 11.

156 The Address of the Seceding Assemblymen, reprinted in Documentary History DigiTAL, supra note 31.

157 See, e.g., David J. Siemers, The Antifederalists: Men of Great Faith and Forbearance 149-50 (2003).

158 Assembly Proceedings, Thursday, 31 January 1788 (excerpt), reprinted in DocUMENTARY History Digital, supra note 31. 
unnecessarily biased people against the new constitution. Benson even suggested, but without elaboration, that the Convention had not exceeded its power by proposing the new constitution. Thus, it is unknown if Benson meant that an amendment could be a complete substitute, that the new constitution preserved enough of the Articles to qualify as an amendment, or that Salus Populi or Necessitas authorized the new constitution. Regardless, Schoonmaker's amendment lost 25 to 27 , and the original resolution passed with related resolutions. ${ }^{159}$

A similar episode occurred when the Senate considered the Assembly's above resolution to hold a state convention. Senator Robert Yates, being consistent with the understanding of amendment he expressed months earlier as a delegate to the Philadelphia Convention in his letter with Lansing to Governor Clinton, motioned for a committee to amend the resolution by adding an introduction similar to Schoonmaker's failed amendment. Senator James Duane objected that the Senate sends only bills and never resolutions to committee for amendment. Yates retorted that state residents should nevertheless know the framers "went beyond their powers" and "have not amended, but made a new system." But Duane, perhaps following Representative Benson's lead, claimed any amendment to the resolution stating that the Philadelphia Convention exceeded its powers would be biased and unnecessary. Duane threatened that "[h]e was ready ... to prove ... the Convention had not exceeded their powers." But Duane continued that "this is not a question to be decided here[.]" Thus, just as with Benson, Duane did not clarify if he thought an amendment could be a complete substitute, Salus Populi or Necessitas authorized the new constitution, or another argument. Yates' motion lost 7 to $12 .{ }^{160}$ Nevertheless, these episodes in the Assembly and Senate indicate many legislators believed the new constitution completely replaced the Articles and thus was not an amendment.

\section{c. Maryland Legislature}

On November 29, 1787, which was two days after the Maryland legislature had called for a state convention to consider ratifying the new constitution, ${ }^{161}$ Luther Martin gave a speech to the House of Delegates of Maryland that passionately opposed the new constitution. Martin was not a member of the House of Delegates, but he had represented Maryland in the Philadelphia Convention and even served on the Convention's committee that proposed the first draft of the Origination Clause. ${ }^{162}$ The House had invited him to recount his experience in Philadelphia.

Among other declarations, Martin condemned the actions of his fellow framers, saying (emphasis added) "we, contrary to the purpose for which we were intrusted [sic], consider[ed] ourselves as master-builders, too proud to amend our original government [the Articles of Confederation] ... [and] demolish[ed] it entirely ... erect[ing] a new system of our own[.]" Martin then warned the House as follows that, given this precedent, a national convention in the future could replace the new constitution:

159 Newspaper Report of Assembly Debates, Thursday, 31 January 1788, reprinted in DocuMENTARY History Digital, supra note 31.

160 Newspaper Report of Senate Debates Friday, 1 February 1788, reprinted in DocumeNTARy History Documentary History Digital, supra note 31.

161 Maggs, Concise Guide, supra note 145, at 468.

162 William L. Reynolds II, Luther Martin, Maryland and the Constitution, 47(1) MD. L. Rev. 291, 298 (1987). 
[A] short time might show the new system as defective as the old [Confederation], perhaps more so. Should a convention be found necessary again, if the members thereof, acting upon the same principles, instead of amending and correcting its defects, should demolish that entirely, and bring forward a third system, that also might soon be found no better than either of the former; and thus we might always remain young in government, and always suffering the inconveniences of an incorrect, imperfect system. ${ }^{163}$

Besides Martin's speech, there are evidently no other published debates from the House that day about whether a state convention should ratify the constitution. ${ }^{164}$ It is unknown how delegates reacted to Martin. Regardless, because such a prominent and influential Marylander as Martin thought that an amendment to the Articles could not be a complete substitute, at least some delegates most likely had shared this view.

\section{Summary of the State Legislatures}

Natelson's evidence from state legislatures during the founding era that amendments could be complete substitutes amounted to two examples of complete substitutes to resolutions, both of which were from the Virginia legislature. All of Natelson's examples of complete substitutes from the legislatures of New Jersey, North Carolina, Pennsylvania, and Massachusetts were examples of only extensive amendments to resolutions or bills.

From debates in state legislatures about the new constitution, I found significant evidence that legislators-Federalists and Anti-Federalists alike-thought an amendment to the Articles of Confederation could not be a complete substitute. For instance, in Pennsylvania, William Robinson argued the new constitution was "new ground" and therefore "no alteration of any particular article of the Confederation, which is the only thing provided for." Also, in New York, many legislators wanted to amend a resolution to declare the Philadelphia Convention violated its alteration power by proposing the new constitution. Other legislators who opposed this amendment declared, without elaboration, that the Convention did not exceed its power. It is possible these legislators thought, as some argued in the Confederation Congress, that Salus Populi or Necessitas authorized the new constitution. Furthermore, in Maryland, Luther Martin articulated what was most likely the view of at least some delegates that the new constitution was a complete substitute to the Articles and thus not an amendment.

1633 FARRAND's RECORDS, supra note 87, at 180.

164 See, e.g., Early State Records Online, Maryland State Archives, available at http://aomol.msa.maryland.gov/html/legislative2.html. The journals of the House of Delegates did not document any reactions to Martin's speech. See Thursday, November 29, 1787, and November 30, 1787, in Votes and Proceedings of the House of Delegates of the State of Maryland, November Session, 1787, available at http://msa.maryland.gov/megafile/ $\mathrm{msa} / \mathrm{speccol} / \mathrm{sc} 4800 / \mathrm{sc} 4872 / 003197 / \mathrm{html} / \mathrm{m} 3197-0802 . \mathrm{html}$ 


\section{E. State Conventions}

Leading up to the state conventions, the preponderance of evidence shows members of the British parliament, Philadelphia Convention, Confederation Congress, and state legislatures consistently suggested amendments could not be complete substitutes. For example, in 1736, a member of the British parliament said, regarding amendments to a bill, "altering the whole [of the bill] ... cannot be done ... for ... the Bill would then be a new Bill." Also, Anti-Federalists, such as John Lansing of the Philadelphia Convention, R.H. Lee of the Confederation Congress, and Representative Cornelius Schoonmaker of the New York Assembly, suggested an amendment to the Articles of Confederation could not be a complete substitute. Even some Federalists, such as James Madison of the Confederation Congress, suggested the amendment power disallowed the proposal of the new constitution. Madison said Salus Populi authorized the proposal.

On November 20,1787, Pennsylvania became the first state to convene to consider ratifying the new constitution. ${ }^{165}$ By December 7 of that year, Delaware was the first state to ratify. ${ }^{166}$ On May 29, 1790, Rhode Island became the last of the 13 states of the Confederation to ratify the constitution. ${ }^{167}$

\section{Natelson's Evidence}

Natelson's primary evidence from the 13 state conventions that the original understanding of the scope of an amendment permits complete substitutes was Anti-Federalist William Grayson's comments in the Virginia Convention about the Origination Clause. Grayson said that, as an amendment to a House bill for raising revenue, "[t]he Senate could strike out every word of the bill, except the word whereas, or any other introductory word, and might substitute new words [and a new bill for raising revenue] of their own." ${ }^{168}$ Natelson noted how James Madison then tempered Grayson's comment by saying "[Grayson] says, that there is no difference between the right of originating bills, and proposing amendments. There is some difference, though not considerable." 169 Zotti and Schmitz, in their article on the Origination Clause discussed earlier, noted Madison further declared, in response to Grayson's argument, that "I suppose the first part of the [Origination] [C]lause [i.e., the requirement that all revenue bills must originate in the House of Representatives] is sufficiently expressed to exclude all [of Grayson's] doubts [that the Senate is unable to originate its own revenue bills as complete substitutes to House revenue bills]. Zotti and Schmitz thus implied that Madison actually contradicted Grayson and declared Senate amendments to House bills for raising revenue could not be complete substitutes that are new bills for raising revenue. ${ }^{170}$

165 George J. Graham, Jr., Pennsylvania: Representation and the Meaning of Republicanism, in Ratifying the Constitution 52 (Michael Allen Gillespie \& Michael Lienesch eds., 1989) [hereinafter RATIFYING].

166 Gaspare J. Saladino, Delaware: Independence and the Concept of a Commercial Republic, in RATIFYING, supra note 165, at 29.

167 Michael Allen Gillespie and Michael Lienesch, Introduction, in RATIFYING, supra note 165 , at 17.

168 Natelson, Origination Clause, supra note 1, at 704.

169 Id.

170 Zotti \& Schmitz, Origination Clause, supra note 43, at 115. 
Natelson also cited an example of a complete substitute in the North Carolina Convention. As Natelson documented, in 1788, some delegates to the North Carolina Convention proposed an amendment that completely replaced a resolution to adopt the new constitution with another advocating for amendments to the new constitution. The Convention permitted the proposal of the amendment, but the amendment failed to pass. ${ }^{171}$

\section{My Evidence}

My article found significant evidence from state conventions that shows the dominant view among the ratifiers was that an amendment to the Articles of Confederation could not be a complete substitute. My evidence is consistent with the evidence of the original understanding of the Origination Clause presented in Zotti's and Schmitz's article. Their article documented many comments by ratifiers suggesting the ratifiers did not contemplate the possibility that the Senate could originate its own revenue bills as complete substitutes to the House's revenue bills. As one of Zotti's and Schmitz's examples, James Wilson of the Pennsylvania Convention said "[t]he two branches [the House and Senate] will serve as checks upon the other; they have the same legislative authorities, except in one instance. Money bills must originate in the House[.." ${ }^{\prime 172}$

To find my evidence that ratifiers thought an amendment to the Articles could not be a complete substitute, I searched Elliot's Debates ${ }^{173}$ and The Documentary History of the Ratification of the Constitution for occurrences of amend and words with the root of amend near the words Articles of Confederation or any words with the root of "confed." I discovered numerous relevant records from the conventions in Pennsylvania, Massachusetts, South Carolina, Virginia, New York, and North Carolina.

\section{a. Pennsylvania Convention}

Two ratifiers in the Pennsylvania Convention argued an amendment to the Articles could not be a complete substitute. On November 26, 1787, the Pennsylvania Convention was several days into debating the new constitution. Anti-Federalist Robert Whitehill, who during the debates about the new constitution in the Pennsylvania legislature claimed the Philadelphia Convention had properly altered the Articles, now argued the contrary. He said that the Philadelphia Convention was supposed to have only "give[n] more powers to [the Confederation] Congress" and that "[a new] general government was not thought of." Whitehill added that "[t]he Convention ... made a plan of their own" and thereby "assumed the power of proposing." 174 Two days later, Whitehill further argued that "[t]he present [new] Constitution is a violation of our engagements under the Confederation. No state nor Convention had such powers." 175

\footnotetext{
Natelson, Origination Clause, supra note 1, at 685.

Zotti \& Schmitz, Origination Clause, supra note 43, at 136.

ELLIOT's DeBATES, supra note 106.

174 Convention Debates, Monday, $26^{\text {th }}$ Nov., 1787, P.M., reprinted in Documentary History Digital, supra note 31.

175 Convention Debates, November 28, 1787, reprinted in Documentary History Digital, supra note 31 .
} 
On December 4, Federalist James Wilson conceded the new constitution, which he viewed as totally different from the Articles, was based on "no power at all," including the Philadelphia Convention's amendment power. Wilson claimed the new constitution was only a proposal from "a private pen" for people to consider. ${ }^{176}$ This argument was consistent with Wilson's argument in the Philadelphia Convention that alterations to the Articles must preserve at least the independence of states from a national government found in the Confederation. After all, the new constitution contained no provision such as the $10^{\text {th }}$ Amendment, which was not ratified until several years later in 1791 and which reads, "[t]he powers not delegated to the United States by the Constitution, nor prohibited by it to the States, are reserved to the States respectively, or to the people." 177

In the same speech, Wilson reiterated how an amendment to the Articles could not be a complete substitute by telling the following story about Alexander Pope, the eighteenth-century poet and a hunchback:

It was customary with him [Pope] to use this phrase; "God mend me!" when any little accident happened. One evening, a link-boy was lighting him along [with a torch], and, coming to a gutter, the boy jumped nimbly, over it. Mr. Pope called to him to turn, adding, "God mend me!"” The arch rogue [boy], turning to light him, looked at him, and repeated, "God mend you! He would sooner make half-a-dozen new ones."

Wilson added that "[t]his [story] would apply to the present [Articles of] Confederation; for it would be easier to make another [constitution] than to amend [the Articles.]"178

At the close of the Pennsylvania Convention, 21 members signed "The Address and Reasons of Dissent of the Minority of the Convention of the State of Pennsylvania to their Constituents." Newspapers throughout the country published the dissent, which said, among other arguments, that the framers "were not appointed for the purpose of framing a new form of government, but ... were expressly confined to altering and amending the present articles of confederation."179

\section{b. Massachusetts Convention}

The Massachusetts Convention featured several comments arguing the new constitution amounted to a complete substitute to the Articles and thus was not an amendment. On January 18, 1788, General William Thompson argued Massachusetts should avoid adopting the new constitution until more states did so. Thompson noted the framers "were sent [to Philadelphia] ... to amend this Confederation; but they made a new creature; and the very setting out of it is unconstitutional." 180

1762 Elliot's Debates, supra note 106, at 470.

177 U.S. CONST. amend. X.

1782 Elliot's Debates, supra note 106, at 470.

179 Dissent of the Minority of the Convention, 18 December 1787, reprinted in DocumenTARY History Digital, supra note 31.

1802 Elliot's Debates, supra note 106, at 61. 
On January 23, Thompson reiterated his above point as follows:

It is my wish she [Massachusetts] may be one of the ... dissenting states [to the new constitution]; then we shall be on our old ground [the Articles], and shall not act unconstitutionally. Some people cry, It [sic] will be a great charge; but it will be a greater charge, and be more dangerous, to make a new one. Let us amend the old Confederation. ${ }^{181}$

For Thompson, the new constitution could have been constitutional if it preserved some of the Articles" "old ground."

Another comment occurred on February 5 when Nathaniel Barrell claimed the new constitution, although "not ... the most perfect system," was justified as follows:

I am convinced the Confederation is essentially deficient, and that it will be more difficult to amend that [Articles] than to reform this [new constitution]; and as I think this [new] Constitution, with all its im] perfections, is excellent, compared with that [confederation], and ... is the best constitution we can now obtain. ${ }^{182}$

Here, Barrell referred to the Articles and the new constitution as different documents. He did not say the new constitution was an amendment to the Articles, but he suggested the Articles was unamendable.

\section{c. South Carolina Convention}

Two ratifiers in the South Carolina Convention argued the new constitution amounted to a complete substitute to the Articles and thus was not an amendment. On January 16, 1788, Charles Pinckney argued for the new constitution but said the following (emphasis added):

Those [at the Philadelphia Convention] who had seriously contemplated the subject [of amending the Articles of Confederation] were fully convinced that a total change of system was necessary--that, however the repair of the Confederation might for a time avert the inconveniences of a dissolution, it was impossible a government of that sort could long unite this growing and extensive country. They also thought that the public mind was fully prepared for the change .... Under these momentous impressions the Convention met, when the first question that naturally presented itself to the view of almost every member ... was the formation of a new [constitution], or the amendment of the existing system [Confederation].... [T] he states were unanimous in preferring a change. They wisely considered that, though the Confederation might possess the great outlines of a general government, yet that it was, in fact, nothing more than a [weak] federal union.... It was sufficient to remark that

181 Id. at 80 .

182 Id. at 161. 
the Convention saw and felt the necessity of establishing a government upon different principles, which, instead of requiring the intervention of thirteen different legislatures between the demand and the compliance, should operate upon the people in the first instance. ${ }^{183}$

Pinckney thus claimed the new constitution, "a total change [to the Articles]," was necessary because amending the Confederation proved impossible. These remarks were consistent with his comment in the Philadelphia Convention that an amendment to the Articles could not be a complete substitute.

The next day, Anti-Federalist Rawlins Lowndes said states should hold another national convention to "add strength to the old Confederation, instead of hastily adopting another [the new constitution.]" He also asked, in reference to the replacement of the Articles with the new constitution by the Philadelphia Convention, "whether a man could be looked on as wise, who, possessing a magnificent building, upon discovering a flaw, instead of repairing the injury, should pull it down, and build another." According to convention notes, Lowndes "could not understand with what propriety the [Philadelphia] Convention proceeded to change the Confederation; for ... the sole object of appointing a convention was to inquire what alterations were necessary in the Confederation[.]" Perhaps feeling outnumbered, Lowndes concluded with a "glowing eulogy on the old Confederation[.]"184

\section{d. Virginia Convention}

On June 4, 1788, two days into the Virginia Convention, several ratifiers opined that the new constitution was totally different from, and thus not an amendment to, the Articles. For instance, Anti-Federalist Patrick Henry wanted the Virginia Convention to hear readings of government documents from before the Philadelphia Convention that showed officials had expected the Philadelphia Convention to revise - not entirely replace - the Articles. Judge Edmund Pendleton objected that these readings would be irrelevant to the Virginia Convention's mission to discuss the new constitution's propriety. However, as follows, Pendleton conceded that the Philadelphia Convention's revision power disallowed complete substitutes: "[T]hose Gentlemen [the framers] were only directed to consider the defects of the old system ... not devise a new one[.] [But] they found ... [the confederation] so thoroughly defective as not to admit a revision, and submitted a new system[.."185

Throughout that day, Henry called the new constitution many names, including "an entire alteration of government," "a proposal that goes to the utter annihilation of the [confederation]," and "a proposal to sever ... [the] confederacy." 186 Henry said the framers "exceeded their power ... [as they] ought to have amended the old system; for this purpose they were solely delegated." 187 Even Federalist Edmund Randolph agreed with Henry's rhetoric, claiming the framers, "[o]n a thorough contemplation of the subject," found the Confederation "impossible to amend" and therefore "suggested $\ldots$ a new plan." "188

\footnotetext{
4 ElLiot's Debates, supra note 106, at 255-56.

Id. at 290.

853 Elliot's Debates, supra note 106, at 6.

186 Id. at $21-22$.

187 Id. at 23.

188 Id. at 26-27.
} 
June 6 saw more such comments by Henry, Randolph, and James Madison. In the following passage, Henry warned that, given what he viewed as the violation by the Philadelphia Convention of its revision power, Virginians who will attend a future U.S. Congress under the new constitution could similarly abuse their powers:

When we trusted the great object of revising the Confederation to the greatest, and best, and most enlightened, of our [Virginia's] citizens, we thought their deliberations would have been solely confined to that revision. Instead of this, a new system, totally different in its nature, and vesting the most extensive powers in Congress, is presented. Will the ten men [Virginians] you are to sent [sic] to [the U.S.] Congress be more worthy than those seven [men who represented Virginia in the Philadelphia Convention] were? If power grew so rapidly in their hands, what may it not do in the hands of others? ${ }^{189}$

Thereby, Henry suggested the new constitution amounted to a complete substitute and thus was not a valid revision to the Articles.

Randolph suggested, with the following remarks, that nothing from the Articles was amendable:

I come now ... to the great inquiry, whether the Confederation be such a government as we ought to continue under.... Did I believe the Confederation was a good thread, which might be broken without destroying its utility entirely, I might be induced to concur in putting it together [with amendments] — but, I am so thoroughly convinced of its incapacity to be mended or spliced, that I would sooner recur to any other expedient.... The Confederation is, of all things the most unsafe, not only to trust to in its present form, but even to amend. ${ }^{190}$

For emphasis, Randolph added that no part of the Articles "deserves to be retained" and that the Confederation was now "an old benefactor." ${ }^{191}$ Randolph had the perfect opportunity to argue that the Convention had amended the Articles by completely replacing it with the new constitution, but he did not.

James Madison discussed how similar the "feeble" Confederation was to other confederacies in history that he considered ineffective, such as the Achaean League of Greek states. In the following quote, Madison did not use the words amend, alter, or revise, but he implied the new constitution was a complete replacement - not an amendment and thus a continuation — of the "fatal" Articles (emphasis added):

If we recur to history, and review the annals of mankind, I undertake to say that no instance can be produced ... of any confederate government that will justify a continuation of the present system [i.e., the Articles], or that will not demonstrate the necessity of this change, and of substituting, for

$189 \quad I d$. at 144.

$190 \mathrm{Id}$. at 80.

191 Id. at 83,84 . 
the present pernicious and fatal plan, the system now under consideration [i.e., the new constitution], or one equally energetic. ${ }^{192}$

Of course, this argument contradicted Madison's argument as Publius that the new constitution was an extensive alteration - not a complete substitute - to the Articles. Nevertheless, both arguments suggested an amendment could not be a complete substitute.

William Grayson provided the Virginia Convention's most intriguing comments regarding how an amendment to the Articles could not be a complete substitute. Of course, Natelson's argument depends significantly on Grayson's comment on June 14 that bill amendments could be complete substitutes, even though Madison immediately contradicted this comment.

Grayson made several comments before June 14 suggesting he thought differently regarding amendments to the Articles. For example, on June 11, Grayson said the Articles' "defects ... cannot be removed but by death," but if men are "capable of freedom and good government," then the Articles "should [nevertheless] be amended." ${ }^{193}$ Grayson thereby said only the Articles' death could remove its defects, precluding the possibility that a complete substitute could do so. Grayson then argued that, if men are incapable of freedom and "can only be governed by force," then the country should "adopt the following government" instead of amending the Articles:

$[\mathrm{H}]$ ave a President for life, choosing his successor at the same time; a Senate for life, with the powers of the House of Lords; and a triennial House of Representatives, with the powers of the House of Commons in England. ${ }^{194}$

Here, Grayson gave the options of amending the Articles or adopting his new, powerful government. He did not say the Convention could create his new government by amending the Articles.

Finally, late in the Convention on June 24 when Grayson argued Virginia should properly amend the new constitution before ratification, he said, "[ $t]$ he late Convention were not [even] empowered totally to alter the present Confederation. The idea was to amend. If they lay before us a thing quite different, we are not bound to accept it." ${ }^{195}$ Here, Grayson distinguished between amending and totally altering the Articles, and he directly contradicted his statement 10 days earlier about how bill amendments could be complete substitutes. This contradiction proves Grayson was unsettled about the meaning of amend, as he used this word differently for bills than the Articles. Therefore, Grayson's contradictory comments, coupled with Madison's immediate contradiction of Grayson when he said Senate amendments to House revenue bills could be complete substitutes, nullify the importance of all of Grayson's comments regarding the meaning of amendment.

\footnotetext{
192 Id. at 129.

193 Id. at $273,278$.

194 Id. at 279.

195 Id. at 614.
} 


\section{e. New York Convention}

Two ratifiers in the New York Convention suggested an amendment to the Articles could not be a complete substitute. On June 19, 1788, two days into the New York Convention, Federalist Robert Livingston explained why the Philadelphia Convention proposed the new constitution as follows (emphasis added):

[A] change ... [was] necessary in the form of the government[.] [W] e could no longer retain the old principle of the confederacy, and were compelled to change its form, we were driven to the necessity of creating a new constitution, and could find no place to rest upon in the old Confederation $[.]^{196}$

So, since the Philadelphia Convention thought nothing of the Confederation was salvageable, Livingston suggested the new constitution was a departure from-not an amendment to - the Articles.

The next day, Federalist Alexander Hamilton argued that, given the Articles' concentration of all national power in the Confederation Congress, ${ }^{197}$ the Philadelphia Convention appropriately replaced the Articles with the new constitution. He said the following (emphasis added):

[I]t appears to me extraordinary, that, while gentlemen in one breath acknowledge that the old Confederation requires many material amendments, they should in the next deny that its defects have been the cause of our political weakness.... Shall we take the old Confederation, as the basis of a new system? ... Certainly not. Will any man, who entertains a wish for the safety of his country, trust the sword [the power to declare war] and the purse [the power to tax] with a single assembly [the Confederation Congress] organized on principles so defective--so rotten? Though we might give to such a government certain powers with safety, yet to give them the full and unlimited powers of taxation and the national forces, would be to establish a despotism; the definition of which is, a government in which all power is concentred [sic] a single body. To take the old Confederation, and fashion it upon these principles, would be establishing a power which would destroy the liberties of the people. These considerations show clearly that a government totally different must be instituted. They had weight in the Convention who formed the new system.... The fundamental principle of the old Confederation is defective; we must totally eradicate and discard this principle before we can expect an efficient government. ${ }^{198}$

However, Hamilton thereby advocated for the new constitution, a "government totally different [from the Confederation]," over any amendment to the Articles, suggesting he did not think a complete substitute could be an amendment. By saying the country must eradicate the "fundamental principle of the old Confederation ...

1962 Elliot's Debates, supra note 106, at 215.

197 The Articles of Confederation did not create an executive or a judicial branch. Only the Confederation Congress, which had such powers as the powers to engage in war and coin money, made national decisions.

1982 Elliot's DeBates, supra note 106, at 231, 233-34. 
before we can expect an efficient government," Hamilton indicated he may have been open to amendments that preserved the Articles' less fundamental principles. This argument was similar to his arguments as Publius that suggested an amendment could preserve only secondary or minor parts of the Articles.

\section{f. North Carolina Convention}

As discussed earlier, Natelson found an example of a complete substitute to a resolution in the North Carolina Convention. However, as with other state conventions, this convention featured several comments that suggested an amendment to the Articles of Confederation could not be a complete substitute. On July 23, 1788, William Davie argued for ratification of the new constitution but made this point (emphasis added):

The business of the [Philadelphia] Convention was to amend the Confederation by giving it additional powers. The present form of Congress being a single body, it was thought unsafe to augment its powers, without altering its organization. [So the Convention created a new constitution.] [But] [t] he act of the Convention is but a mere proposal, similar to the production of a private pen. ${ }^{199}$

Davie thereby implied the new constitution was so different from the Confederation that the new constitution was a "mere proposal" and not an amendment.

In the following passage from July 30, Anti-Federalist William Lenoir lambasted the new constitution as a violation of the Philadelphia Convention's amendment power (emphasis added):

When we consider this system collectively [the new constitution], we must be surprised to think that any set of men, who were delegated to amend the Confederation, should propose to annihilate it; for that and this system are utterly different, and cannot exist together... [I]t appears to me, and every other member of this committee, that they [the framers] exceeded their powers. Those gentlemen had no sort of power to form a new constitution altogether[.] $]^{200}$

Lenoir then warned that, given what he viewed as this precedent for permitting an amendment to be a complete substitute, "it may be thought proper, by a few designing persons, to destroy it [the new constitution], in a future age, in the same manner that the old system [the confederation] is laid aside."201

Federalist Richard Spaight opposed Lenoir's argument that the Philadelphia Convention exceeded its power. Spaight, who attended the Philadelphia Convention, made this argument (emphasis added):

I deny the [Lenoir's] charge [that the framers exceeded their powers]. We were sent with a full power to amend the existing system. This involved

1994 Elliot's Debates, supra note 106, at 23.

$200 I d$. at 201.

201 Id. at 203. 
every power to make every alteration necessary to meliorate and render it perfect. It cannot be said that we arrogated powers altogether inconsistent with the object of our delegation. There is a clause which expressly provides for future amendments, and it is still in your power. What the Convention has done is a mere proposal. It was found impossible to improve the old system without changing its very form; for by that system the three great branches of government are blended together [into the Confederation Congress]. All will agree that the concession of a power to a government so constructed is dangerous. The proposing a new system ... arose from the necessity of the case. ${ }^{202}$

However, Spaight thus borrowed William Davie's earlier argument that the new constitution was not an amendment but rather a "mere proposal" based on the situation's necessity.

\section{Summary of the State Conventions}

Natelson presented evidence from state conventions that ratifiers thought amendments could be complete substitutes. His evidence amounted to 1) William Grayson's remark on June 14, 1788, in the Virginia Convention, to which Madison immediately objected, that the Senate's power to amend House bills for raising revenue permits complete substitutes and 2) an example of a complete substitute to a resolution in the North Carolina Convention.

My evidence from state conventions suggests the dominant view among the ratifiers - Federalists and Anti-Federalists alike - was that an amendment to the Articles could not be a complete substitute. For instance, in the Massachusetts Convention, General William Thompson said the framers "were sent [to Philadelphia] ... to amend this Confederation; but they made a new creature[.]" In the Virginia Convention, Grayson even later contradicted his above statement that amendments could be complete substitutes. When discussing the new constitution's propriety on June 24, Grayson claimed the new constitution "totally ... alter[ed]" the Articles and thus was not an amendment. Such remarks by Thompson and Grayson were predictable given the wealth of evidence from the British parliament, Philadelphia Convention, Confederation Congress, and state legislatures indicating amendments could not be complete substitutes. Thus, the preponderance of evidence from the state conventions suggests the original understanding of the scope of an amendment disallows complete substitutes.

\section{CONCLuSion}

My examination of founding-era dictionaries and analysis of various writings from the ratification period discovered the original public meaning of amendment in the Origination Clause. This meaning of amendment is a change or alteration to something that must 1) be germane to that something, 2) preserve at least the

202 Id. at 206-07. 
essence of a significant part of the substance of that something (a "significant part" being a distinct portion that served a function within that something), and 3) make that something transform from bad to better.

Natelson argued the original understanding of the scope of an amendment permits complete substitutes. His evidence amounted to 1) William Grayson's remark at the Virginia Convention, to which Madison immediately objected, that the meaning of the word amendment in the Origination Clause permits complete substitutes, 2) an example of a complete substitute to a resolution during the North Carolina Convention, and 3) two examples of complete substitutes to resolutions in the Virginia legislature.

However, as shown in my article, the preponderance of evidence leading up to and from the state conventions suggests the original understanding of the scope of an amendment actually disallows complete substitutes. For one, in the decades leading up to the founding, members of the British parliament consistently suggested bill amendments could not be complete substitutes, such as in 1736 when a lord said a bill amendment could never alter the whole of a bill because "the Bill would then be a new Bill." Also, much evidence from the Philadelphia Convention, Confederation Congress, state legislatures, and state conventions suggests the dominant view among the founders was that an amendment to the Articles of Confederation could not be a complete substitute. For instance, in the Philadelphia Convention, James Wilson explained what he believed was the limit of the scope of the Convention's alteration power. "[E]very article [of the Articles] may be totally altered," he said, "except that $\mathrm{wh}[\mathrm{ich}]$ destroys the Idea of a confedy [confederation]." And late in the Virginia Convention, Grayson officially switched his position about the propriety of complete substitutes and argued the Philadelphia Convention "totally ... alter[ed]" the Articles when "[t]he idea was to amend."

The original public meaning of the scope of an amendment provides a new definition of a complete substitute to a bill. As discussed earlier, Natelson's definition of a complete substitute focuses on whether an amendment preserves any exact language of a bill. He said a complete substitute occurs when (emphasis added) "all the language in a bill...after the enacting clause (or after some other clause very early in the text) [i]s removed and replaced with new language." However, according to the original public meaning of the scope of an amendment, a complete substitute occurs when every significant part of the substance of a bill, including the essence of every significant part, is removed and replaced with a new part(s).

It is therefore simple to determine if PPACA or any other amendment by the Senate to a House bill for raising revenue that is a new bill for raising revenue complies with the original public meaning of the scope of an amendment. One should ask if the given amendment preserved at least the essence of a significant part of the substance of the respective bill. PPACA, as the Senate's amendment to the House's Service Members bill, replaced every significant part of the substance of the Service Members bill, including the essence of every significant part, with new parts. PPACA preserved only the number of the Service Members bill, which was H.R. 3590 and which obviously served no function within the Service Members bill. PPACA thus was a complete substitute to the Service Members bill and violates the original public meaning of the scope of an amendment in the Origination Clause. 


\section{Appendix: Additional Ratification Records That Suggest Amendments Could Not Be Complete Substitutes}

\begin{tabular}{|c|c|c|}
\hline Source & Record & Excerpt (emphasis added) \\
\hline \multirow[t]{3}{*}{$\begin{array}{c}\text { DocumENTARY } \\
\text { History Digital, } \\
\text { supra note } 31 .\end{array}$} & $\begin{array}{l}\text { 1. Richard Henry Lee } \\
\text { to George Mason, } \\
\text { New York, October } \\
1,1787 .\end{array}$ & $\begin{array}{l}\text { I might inform you how the Convention plan of } \\
\text { Government was entertained by [the Confederation] } \\
\text { Congress ... Upon due consideration of the } \\
\text { Constitution under which we now Act, some of us } \\
\text { were clearly of opinion that the 13th article of the } \\
\text { Confederation [the alteration power] precluded } \\
\text { us from giving an opinion concerning a plan } \\
\text { subversive of the present system and eventually } \\
\text { forming a New Confederacy[.] }\end{array}$ \\
\hline & $\begin{array}{l}\text { 2. Edward Carrington } \\
\text { to Thomas } \\
\text { Jefferson, New } \\
\text { York, October 23, } \\
1787 .\end{array}$ & $\begin{array}{l}\text { I have been honoured with your favor of the 4th. } \\
\text { of August. Inclosed [sic] you will receive a Copy } \\
\text { of the report of our late federal Convention, which } \\
\text { presents, not amendments to the old Confederation, } \\
\text { but an entire new Constitution. }\end{array}$ \\
\hline & $\begin{array}{l}\text { 3. The Impartial } \\
\text { Examiner } \\
\text { I, Virginia } \\
\text { Independent } \\
\text { Chronicle, February } \\
20,1788 .\end{array}$ & $\begin{array}{l}\text { [Arguing against the new constitution, the Impartial } \\
\text { Examiner said the following:] To the free people of } \\
\text { VIRGINIA. Countrymen and Fellow-Citizens.... } \\
\text { that this system [the Articles] has prevailed } \\
\text { but a few years; and now already a change, a } \\
\text { fundamental change [the new constitution] therein } \\
\text { is meditated... The best regulated governments } \\
\text { have their defects, and might perhaps admit of } \\
\text { improvement: but the great difficulty consists in } \\
\text { clearly discovering the most exceptionable parts } \\
\text { and judiciously applying the amendments. A wise } \\
\text { nation will, therefore, attempt innovations of this } \\
\text { kind with much circumspection. They will view the } \\
\text { political fabric, which they have once reared, as } \\
\text { the sacred palladium of their happiness; - they will } \\
\text { touch it, as a man of tender sensibility toucheth the } \\
\text { apple of his eye,- - they will touch it with a light, } \\
\text { with a trembling-with a cautious hand,-lest } \\
\text { they injure the whole structure in endeavoring to } \\
\text { reform any of its parts. In small and trivial points } \\
\text { alterations may be attempted with less danger; } \\
\text { but-where the very nature, the essence of the thing } \\
\text { is to be changed: when the foundation itself is to } \\
\text { be transformed, and the whole plan entirely new } \\
\text { modelled;- should you not hesitate, O Americans? }\end{array}$ \\
\hline
\end{tabular}




\begin{tabular}{|c|c|c|}
\hline Source & Record & Excerpt (emphasis added) \\
\hline \multirow[t]{4}{*}{$\begin{array}{c}\text { DOCUMENTARY } \\
\text { HistORY DigITAL, } \\
\text { supra } \text { note } 31 .\end{array}$} & $\begin{array}{l}\text { 4. A Federal } \\
\text { Republican, Norfolk } \\
\text { and Portsmouth } \\
\text { Journal, March 5, } \\
1788 \text {. }\end{array}$ & $\begin{array}{l}\text { When these Deputies [in the Philadelphia } \\
\text { Convention] met, instead of confining themselves } \\
\text { to the powers with which they were entrusted, } \\
\text { they pronounced all amendments to the articles of } \\
\text { Confederation wholly impracticable, and with a } \\
\text { spirit of amity and concession truly remarkable! } \\
\text { proceeded to form a government entirely new, and } \\
\text { totally different in its principles and organization. }\end{array}$ \\
\hline & $\begin{array}{l}\text { 5. Federal Farmer, } \\
\text { Letters to the } \\
\text { Republican, } \\
\text { November } 8,1787 .\end{array}$ & $\begin{array}{l}\text { [Below, the Federal Farmer proclaimed that } \\
\text { opponents of the new constitution should propose } \\
\text { amendments to the new constitution or propose } \\
\text { "some other system of government" as } \\
\text { "a substitute." He did not suggest an amendment to } \\
\text { the new constitution could be another entirely new } \\
\text { constitution, and he thereby implied amendments } \\
\text { could not be complete substitutes.] I admit } \\
\text { improper measures are taken against the adoption } \\
\text { of the system [the new constitution] as well as for } \\
\text { it-all who object to the plan proposed ought to } \\
\text { point out the defects objected to, and to propose } \\
\text { those amendments with which they can accept it, or } \\
\text { to propose some other system of government, that } \\
\text { the public mind may be known, and that we may be } \\
\text { brought to agree in some system of government, to } \\
\text { strengthen and execute the present, or to provide a } \\
\text { substitute. }\end{array}$ \\
\hline & $\begin{array}{l}\text { 6. A Countryman I } \\
\text { (Hugh Hughes), } \\
\text { New York Journal, } \\
\text { November 21, } \\
1787 .\end{array}$ & $\begin{array}{l}\text { [W] hen I consider the original Confederation, and } \\
\text { Constitutions of the States which compose the } \\
\text { Union, as well as the Resolutions of several of } \\
\text { the States, for calling a Convention to amend the } \\
\text { Confederation, which it admits, but not a new one, } \\
\text { I am greatly at a Loss to account for the surprizing } \\
\text { [sic] Conduct of so many wise Men, as must have } \\
\text { composed that honorable Body. In fact, I do not } \\
\text { know, at present, whether it can be accounted } \\
\text { for; unless it be by supposing a Predetermination } \\
\text { of a Majority of the Members to reject their } \\
\text { Instructions, and all authority under which they } \\
\text { acted.... However, I do not even wish to think so } \\
\text { unfavorably of the Majority; but rather, that several } \\
\text { of them, were, by different Means, insidiously } \\
\text { drawn into the Measures of the more artful and } \\
\text { designing Members, who have long envied the } \\
\text { great Body of the People, in the United States, the } \\
\text { Liberties which they enjoy. }\end{array}$ \\
\hline & $\begin{array}{l}\text { 7. A Citizen, New York } \\
\text { Journal, November } \\
24,1787 .\end{array}$ & $\begin{array}{l}{[\mathrm{T}] \text { he business of the conventioneers [in }} \\
\text { Philadelphia] was then evidently not to form a new } \\
\text { constitution for the United States, but to revise and } \\
\text { amend the old one, as far as was necessary and } \\
\text { consistent with their delegation. }\end{array}$ \\
\hline
\end{tabular}




\begin{tabular}{|c|c|c|}
\hline Source & Record & Excerpt (emphasis added) \\
\hline \multirow[t]{4}{*}{$\begin{array}{c}\text { DOCUMENTARY } \\
\text { HiSTORY DiGITAL, } \\
\text { supra note } 31 .\end{array}$} & $\begin{array}{ll}\text { 8. } & \text { A Countryman II } \\
\text { (De Witt Clinton), } \\
\text { New York Journal, } \\
\text { December 13, } 1787 .\end{array}$ & $\begin{array}{l}\text { [While arguing against the new constitution } \\
\text { by recalling a conversation with his neighbor, } \\
\text { a Countryman said the following:] [H]e [my } \\
\text { neighbor] said at the same time, that though my } \\
\text { letter was very long, I had not been quite plain } \\
\text { enough about one thing, for, he said, we should be } \\
\text { careful not to give a bit more power to our rulers } \\
\text { than we could well help; for they would always } \\
\text { find a way to get more fast enough, and they knew } \\
\text { how to keep it when they once had it, so that we } \\
\text { could never get any part of it back again; and } \\
\text { to prove what he said, he put me in mind, that } \\
\text { the convention was only sent to amend the old } \\
\text { constitution, yet they sat about making a new one, } \\
\text { though they had no power to do that at all[.] }\end{array}$ \\
\hline & $\begin{array}{l}\text { 9. The Republican } \\
\text { Federalist I, } \\
\text { Massachusetts } \\
\text { Centinel, December } \\
\text { 29, } 1787 \text {. }\end{array}$ & $\begin{array}{l}\text { [T] he delegates [to the Philadelphia Convention] } \\
\text { of the State [of Massachusetts] were to report } \\
\text { measures not for abolishing but for preserving the } \\
\text { articles of Confederation; for amending them; and } \\
\text { for increasing their powers consistently with the } \\
\text { true republican spirit and genius thereof[.] }\end{array}$ \\
\hline & $\begin{array}{l}\text { 10. Agrippa X, } \\
\text { Massachusetts } \\
\text { Gazette, January 1, } \\
1788 .\end{array}$ & $\begin{array}{l}\text { [Below, Agrippa argued for amending the Articles } \\
\text { of Confederation instead of adopting the new } \\
\text { constitution. This argument indicated he thought } \\
\text { the new constitution was a complete substitute } \\
\text { to the Articles and thus not an amendment.] It is } \\
\text { easier to amend the old confederation, defective } \\
\text { as it has been represented, than it is to correct the } \\
\text { new form ... By adopting the form proposed by } \\
\text { the [Philadelphia] convention, you will have the } \\
\text { derision of foreigners, internal misery, and the } \\
\text { anathemas of posterity. By amending the present } \\
\text { confederation, and granting limited powers to } \\
\text { Congress, you secure the admiration of strangers, } \\
\text { internal happiness, and the blessings and prosperity } \\
\text { of all succeeding generations. Be wise then, and } \\
\text { by preserving your freedom, prove, that Heaven } \\
\text { bestowed it not in vain. }\end{array}$ \\
\hline & $\begin{array}{l}\text { 11. Samuel, } \\
\text { Independent } \\
\text { Chronicle, January } \\
10,1788 .\end{array}$ & $\begin{array}{l}\text { This [new] Constitution does not wear the } \\
\text { complexion of uniting the nation-but of dividing } \\
\text { it. Had we not much better keep on our old } \\
\text { ground? The national covenant we are under [the } \\
\text { Articles of Confederation], solemnly ratified to } \\
\text { be perpetual, and amend that: It is, no doubt, as } \\
\text { easy to amend that, as it will be to amend the new } \\
\text { one. And this I understand, was the sole purpose } \\
\text { the federal Convention was appointed for, viz. To } \\
\text { revise the articles of confederation, not to destroy } \\
\text { the covenant. Why should we be fond of another } \\
\text { revolution so soon? Why should we be fond of such } \\
\text { an innovation? }\end{array}$ \\
\hline
\end{tabular}




\begin{tabular}{|c|c|c|c|}
\hline Source & & Record & Excerpt (emphasis added) \\
\hline \multirow[t]{2}{*}{$\begin{array}{l}\text { DOCUMENTARY } \\
\text { HISTORY DIGITAL, } \\
\text { supra } \text { note } 31 .\end{array}$} & & $\begin{array}{l}\text { Ezra, Massachusetts } \\
\text { Centinel, January } \\
23,1788 .\end{array}$ & $\begin{array}{l}\text { Mr. PRINTER, The question with regard to } \\
\text { the adoption or rejection of the [new] federal } \\
\text { Constitution, now under consideration of the } \\
\text { [Massachusetts] Convention, representing the } \\
\text { several corporations of this Commonwealth, and } \\
\text { now sitting in the town of Boston, is a question } \\
\text { which ought to be maturely debated, and soberly } \\
\text { judged upon; should this take place. I imagine } \\
\text { the result must be, a rejection of the [new] } \\
\text { Constitution ... They (the people) are willing the } \\
\text { federal Convention, should return to Philadelphia, } \\
\text { and accomplish the business for which they were } \\
\text { delegated, viz. to amend the Confederation. }\end{array}$ \\
\hline & & $\begin{array}{l}\text { Agrippa XVI, } \\
\text { Massachusetts } \\
\text { Gazette, February } \\
\text { 5, } 1788 .\end{array}$ & $\begin{array}{l}\text { [Below, Agrippa argued that it would be better to } \\
\text { amend the Articles of Confederation than to pass } \\
\text { and then amend the new constitution. He referred } \\
\text { to the new constitution as the "new constitution," } \\
\text { "new one," and "proposed constitution." He } \\
\text { stated the "confederation amended would be } \\
\text { infinitely preferable to the proposed constitution." } \\
\text { All this language suggests he thought the new } \\
\text { constitution was a complete substitute to the } \\
\text { Articles and thus not an amendment. Otherwise, } \\
\text { he would have called the new constitution the } \\
\text { "confederation amended."] I confess that I have } \\
\text { yet seen no sufficient reason for not amending the } \\
\text { confederation, though I have weighed the argument } \\
\text { with candour. I think it would be much easier to } \\
\text { amend it than the new constitution. But this is a } \\
\text { point on which men of very respectable character } \\
\text { differ ... Another reason which I had in stating the } \\
\text { amendments to be made [to the new constitution], } \\
\text { was to shew how nearly those who are for } \\
\text { admitting the system with the necessary alterations, } \\
\text { agree with those who are for rejecting this system } \\
\text { and amending the confederation. In point of } \\
\text { convenience, the confederation amended would be } \\
\text { infinitely preferable to the proposed constitution. In } \\
\text { amending the former, we know the powers granted, } \\
\text { and are subject to no perplexity; but in reforming } \\
\text { the latter, the business is excessively intricate, and } \\
\text { great part of the checks on Congress are lost... } \\
\text { If it [the new constitution] is rejected, the resolve } \\
\text { should contain the amendations [sic] of the old } \\
\text { system; and accepted, it [the resolve] should } \\
\text { contain the corrections of the new one. }\end{array}$ \\
\hline
\end{tabular}




\begin{tabular}{|c|c|c|}
\hline Source & Record & Excerpt (emphasis added) \\
\hline \multirow[t]{2}{*}{$\begin{array}{c}\text { DOCUMENTARY } \\
\text { HISTORY } \\
\text { DIGITAL, } \\
\text { supra } \text { note } 31 .\end{array}$} & $\begin{array}{l}\text { 14. A Friend to Good } \\
\text { Government, } \\
\text { Poughkeepsie } \\
\text { Country Journal, } \\
\text { April 8, 1788. }\end{array}$ & $\begin{array}{c}\text { [Below, a Friend to Good Government argued the } \\
\text { new constitution preserved enough of the Articles } \\
\text { of Confederation, including the union among states, } \\
\text { to be a valid alteration and amendment.] } \\
\text { [B]ut it was soon found even before the expiration } \\
\text { of the war, that the confederation was too feeble, } \\
\text { and very inadequate to the public exigencies... } \\
\text { [T] his give [sic] rise to the Convention that } \\
\text { framed the [new] Constitution, in question; they } \\
\text { were appointed by the State Legislatures, and } \\
\text { empowered by the letter of the authority under } \\
\text { which they acted to report such alterations and } \\
\text { amendments in the Confederation as would render } \\
\text { the federal government adequate to the exigencies } \\
\text { of government and the preservation of the Union- } \\
\text { you will here perceive that the latitude given in the } \\
\text { instruction, were amply large enough to justify the } \\
\text { measures the Convention have taken. The objects } \\
\text { in view were the welfare and preservation of the } \\
\text { Union, and their business so far to new model our } \\
\text { government as to encompass those objects. }\end{array}$ \\
\hline & $\begin{array}{l}\text { 15. A Plebeian, An } \\
\text { Address to the } \\
\text { People of the State } \\
\text { of New York, April } \\
\text { 17, } 1788 .\end{array}$ & $\begin{array}{l}\text { [Below, a Plebeian said that the new constitution } \\
\text { was a "new form of government" that was } \\
\text { "an entire change in the nature of our federal } \\
\text { government." He implied that the new constitution } \\
\text { was thus not an alteration to the Articles of } \\
\text { Confederation.] Previous to the meeting of } \\
\text { the convention, the subject of a new form of } \\
\text { government had been little thought of, and scarcely } \\
\text { written upon at all. It is true, it was the general } \\
\text { opinion, that some alterations were requisite in the } \\
\text { federal system. This subject had been contemplated } \\
\text { by almost every thinking man in the union. It had } \\
\text { been the subject of many well-written essays, } \\
\text { and was the anxious wish of every true friend to } \\
\text { America. But it never was in the contemplation } \\
\text { of one in a thousand of those who had reflected } \\
\text { on the matter, to have an entire change in the } \\
\text { nature of our federal government- to alter it from } \\
\text { a confederation of states, to that of one entire } \\
\text { government, which will swallow up that of the } \\
\text { individual states. I will venture to say, that the idea } \\
\text { of a government similar to the one proposed, never } \\
\text { entered the mind of the legislatures who appointed } \\
\text { the convention, and of but very few of the members } \\
\text { who composed it, until they had assembled and } \\
\text { heard it proposed in that body: much less had the } \\
\text { people any conception of such a plan until after it } \\
\text { was promulgated. }\end{array}$ \\
\hline
\end{tabular}




\begin{tabular}{|c|c|c|}
\hline Source & Record & Excerpt (emphasis added) \\
\hline \multirow[t]{4}{*}{$\begin{array}{c}\text { DOCUMENTARY } \\
\text { HISTORY } \\
\text { DIGITAL, } \\
\text { supra } \text { note } 31 .\end{array}$} & $\begin{array}{l}\text { 16. New York Federal } \\
\text { Republican } \\
\text { Committee (John } \\
\text { Lamb) to Richard } \\
\text { Henry Lee, New } \\
\text { York, May 18, } \\
1788 .\end{array}$ & $\begin{array}{l}\text { [Below, the New York Federal Republican } \\
\text { Committee said that alterations to the } \\
\text { Confederation are needed and that the new } \\
\text { government "proposed in its Room" would be } \\
\text { dangerous to liberty. This language suggests the } \\
\text { committee thought the new constitution was a } \\
\text { complete substitute to the Articles and thus not an } \\
\text { alteration.] The System of Government proposed by } \\
\text { the late [Philadelphia] Convention to the respective } \\
\text { States for their Adoption, involves in it Questions } \\
\text { and Consequences in the highest Degree interesting } \\
\text { to the People of these States. While we see, in } \\
\text { common with our Brethren of the other States, } \\
\text { the Necessity of making Alterations in the present } \\
\text { existing federal Government [confederation], } \\
\text { we cannot but apprehend that the one [the new } \\
\text { constitution] proposed in its Room contains in it } \\
\text { Principles dangerous to public Liberty and Safety. }\end{array}$ \\
\hline & $\begin{array}{l}\text { 17. Sydney, New York } \\
\text { Journal, June 13, } \\
1788 .\end{array}$ & $\begin{array}{l}\text { TO THE CITIZENS OF THE STATE OF NEW- } \\
\text { YORK.... [A]s from every circumstance we } \\
\text { have reason to infer that the new constitution } \\
\text { does not originate from a pure source[.] It was } \\
\text { an outrageous violation in the [Philadelphia] } \\
\text { convention on the 17th September, 1787, to attempt } \\
\text { a consolidation of the union and utterly destroy the } \\
\text { confederation, and the sovereignty of particular } \\
\text { states, when their powers were restricted "to the } \\
\text { sole and express purpose of revising and amending } \\
\text { the confederation." }\end{array}$ \\
\hline & $\begin{array}{l}\text { 18. Richard Henry Lee } \\
\text { to Samuel Adams } \\
\text { Chantilly, April 28, } \\
1788 .\end{array}$ & $\begin{array}{l}\text { [T] hough it were admitted that some amendments } \\
\text { to the present confederation would better } \\
\text { promote the ends designed by it, why, for that } \\
\text { reason, exterminate the present plan [Articles of } \\
\text { Confederation], and establish on its ruins another } \\
\text { [the new constitution], so replete with power, } \\
\text { danger, and hydra-headed mischief? }\end{array}$ \\
\hline & $\begin{array}{l}\text { 19. John De Witt II, } \\
\text { American Herald, } \\
\text { October 29, } 1787 .\end{array}$ & $\begin{array}{l}\text { In my last address upon the proceedings of the } \\
\mathrm{F}[\mathrm{e}] \mathrm{deral} \text { [Philadelphia] Convention, I endeavored } \\
\text { to convince you of the importance of the subject, } \\
\text { that it required a cool, dispassionate examination, } \\
\text { and a thorough investigation, previous to its } \\
\text { adoption - that it [the new constitution] was } \\
\text { not a mere revision and amendment of our first } \\
\text { Confederation, but a compleat [sic] System for the } \\
\text { future government of the United States[.] }\end{array}$ \\
\hline
\end{tabular}




\begin{tabular}{|c|c|c|}
\hline Source & Record & Excerpt (emphasis added) \\
\hline \multirow[t]{5}{*}{$\begin{array}{l}\text { DOCUMENTARY } \\
\text { HISTORY } \\
\text { DIGITAL, } \\
\text { supra } \text { note } 31 .\end{array}$} & $\begin{array}{l}\text { 20. John De Witt V, } \\
\text { American Herald, } \\
\text { December 3, } 1787 .\end{array}$ & $\begin{array}{l}\text { To the FREE CITIZENS of the } \\
\text { COMMONWEALTH of MASSACHUSETTS.... } \\
\text { And do you discover a desire in those who wish } \\
\text { you to embrace this Government, to inform you } \\
\text { of its principles, and the consequences which will } \\
\text { probably ensue from such principles - why they } \\
\text { [the framers] have taken from you the sinews of } \\
\text { your present government, and instead of revising } \\
\text { and amending your Confederation; have handed } \\
\text { you a new one, contrasted in the plenitude of its } \\
\text { powers. }\end{array}$ \\
\hline & $\begin{array}{l}\text { 21. Cornelius, } \\
\text { Hampshire } \\
\text { Chronicle, } \\
\text { December } 11,1787 .\end{array}$ & $\begin{array}{l}\text { It may be observed in the first place, that this } \\
\text { [new] constitution is not an amendment of the } \\
\text { confederation, in the manner therein stipulated; } \\
\text { but it is an in tire [entire] subversion of that solemn } \\
\text { compact. }\end{array}$ \\
\hline & $\begin{array}{l}\text { 22. Elbridge Gerry to } \\
\text { the [Massachusetts] } \\
\text { General Court New } \\
\text { York, October } 18, \\
1787 .\end{array}$ & $\begin{array}{l}\text { As the [Philadelphia] Convention was called for } \\
\text { "the sole \& express purpose of revising the articles } \\
\text { of confederation, \& reporting to Congress \& the } \\
\text { several Legislatures such alterations \& provisions } \\
\text { as shall render the federal Constitution adequate to } \\
\text { the exigencies of Government, \& the preservation } \\
\text { of the union," I did not conceive that these powers } \\
\text { extended to the formation of the plan proposed, } \\
\text { but the Convention being of a different opinion, } \\
\text { I acquiesced in it, being fully convinced that to } \\
\text { preserve the union, an efficient Government was } \\
\text { indispensibly [sic] necessary; \& that it would be } \\
\text { difficult to make proper amendments to the articles } \\
\text { of confederation. }\end{array}$ \\
\hline & $\begin{array}{ll}\text { 23. } & \text { Sidney, Albany } \\
\text { Gazette, January } \\
24,1788 .\end{array}$ & $\begin{array}{l}\text { [T]hey call themselves federalists, when, in the } \\
\text { same breath, they do not hesitate to say, they mean } \\
\text { to destroy! entirely to destroy the confederation!... } \\
\text { upon the start of the late convention, when } \\
\text { they refused to be guided by their credentials } \\
\text { (which expressly confined their powers to be for } \\
\text { the sole purpose of revising and amending the } \\
\text { confederation) and presuming to recommend to the } \\
\text { people this new instrument[.] }\end{array}$ \\
\hline & $\begin{array}{l}\text { 24. Thomas Lee } \\
\text { Shippen to William } \\
\text { Shippen, Jr., } \\
\text { London, November } \\
\text { 20, } 1787 .\end{array}$ & $\begin{array}{l}\text { They [the Articles of Confederation] had perhaps } \\
\text { some defects, but they were easy to be remedied. } \\
\text { Impatient of temporary inconveniences, you have } \\
\text { rashly overthrown the system which was the gift } \\
\text { of Heaven and have lost sight of a great object } \\
\text { for which you have so nobly fought and bled in } \\
\text { a } 7 \text { years war. You had erected a fine and stately } \\
\text { fabric whereof some key stones were wanting, } \\
\text { and which you should with a modest and reverent } \\
\text { hand have endeavored to supply, but instead of } \\
\text { that, to amend its [the Articles'] defects you have } \\
\text { demolished \& destroyed the whole building, and I } \\
\text { think sacrilegiously. }\end{array}$ \\
\hline
\end{tabular}




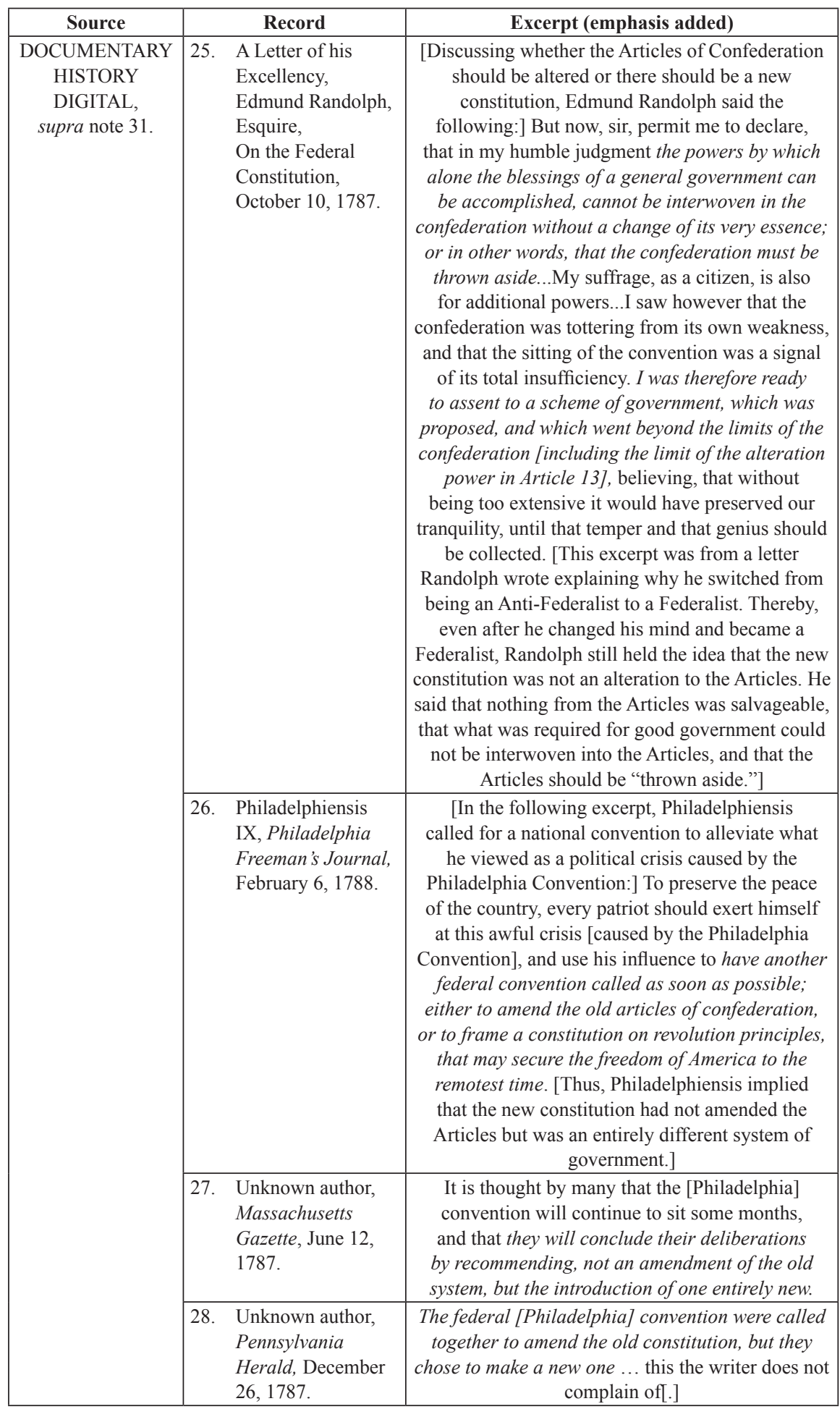




\begin{tabular}{|c|c|c|}
\hline Source & Record & Excerpt (emphasis added) \\
\hline $\begin{array}{l}\text { Friends Of The } \\
\text { Constitution, } \\
\text { supra note } 41 .\end{array}$ & $\begin{array}{l}\text { 29. Cato Essay, } \\
\text { Country Journal } \\
\text { and Advertiser, } \\
\text { Poughkeepsie, } \\
\text { December 12, 1787, } \\
\text { at } 345 .\end{array}$ & $\begin{array}{l}\text { The radical defects in the constitution of } \\
\text { the confederate government [the Articles of } \\
\text { Confederation], was too obvious to escape the } \\
\text { notice of a sensible, enlightened people.... It is } \\
\text { but a groveling business, and commonly ruinous } \\
\text { policy, to repair by peace-meal a shattered } \\
\text { defective fabric - it is better to raise the disjointed } \\
\text { building to its formation, and begin a new. The } \\
\text { confederation was fraught with so many defects, } \\
\text { and these so interwoven with its substantial parts, } \\
\text { that to have attempted to revise it would have been } \\
\text { doing business by the halves, and therefore the } \\
\text { Convention with a boldness and decision becoming } \\
\text { freemen, wisely carried the remedy to the root of } \\
\text { the evil; and have offered a form of government to } \\
\text { your consideration on an entire new system-much } \\
\text { depends on your present deliberations. }\end{array}$ \\
\hline \multirow[t]{3}{*}{$\begin{array}{l}\text { ANTI-FEDERALIST } \\
\text { PAPERS, } \\
\text { supra } \text { note } 42 .\end{array}$} & $\begin{array}{l}\text { 30. A Federal } \\
\text { Republican, The } \\
\text { Power Vested } \\
\text { in Congress of } \\
\text { Sending Troops } \\
\text { for Suppressing } \\
\text { Insurrections Will } \\
\text { Always Enable } \\
\text { Them to Stifle the } \\
\text { First Struggles of } \\
\text { Freedom, March 5, } \\
\text { 1788, at 19. }\end{array}$ & $\begin{array}{l}\text { Upon this principle, a general convention of the } \\
\text { United States [the Philadelphia Convention] was } \\
\text { proposed to be held, and deputies were accordingly } \\
\text { appointed by twelve of the states charged with } \\
\text { power to revise, alter, and amend the Articles of } \\
\text { Confederation. When these deputies met, instead of } \\
\text { confining themselves to the powers with which they } \\
\text { were entrusted, they pronounced all amendments to } \\
\text { the Articles of Confederation wholly impracticable; } \\
\text { and with a spirit of amity and concession truly } \\
\text { remarkable proceeded to form a government } \\
\text { entirely new, and totally different in its principles } \\
\text { and its organization. }\end{array}$ \\
\hline & $\begin{array}{l}\text { 31. A Farmer and } \\
\text { Planter, On the } \\
\text { Motivations and } \\
\text { Authority of the } \\
\text { Founding Fathers, } \\
\text { date not provided, } \\
\text { at } 110 .\end{array}$ & $\begin{array}{l}\text { That they [the framers] exceeded their power is } \\
\text { perfectly clear .... The federal [Philadelphia] } \\
\text { Convention ought to have amended the old system; } \\
\text { for this purpose they were solely delegated; the object } \\
\text { of their mission extended to no other consideration. } \\
\text { You must, therefore, forgive the solicitation of one } \\
\text { unworthy member to know what danger could have } \\
\text { arisen under the present Confederation, and what are } \\
\text { the causes of this proposal [the new constitution] to } \\
\text { change our government. }\end{array}$ \\
\hline & $\begin{array}{l}\text { 32. Patrick Henry, On } \\
\text { the Motivations and } \\
\text { Authority of the } \\
\text { Founding Fathers, } \\
\text { date not provided, } \\
\text { at } 110 .\end{array}$ & $\begin{array}{l}\text { A comparison of the authority under which the } \\
\text { [Philadelphia] convention acted, and their form } \\
\text { of government, will show that they have despised } \\
\text { their delegated power [to alter the Articles of } \\
\text { Confederation], and assumed sovereignty; that they } \\
\text { have entirely annihilated the old confederation, and } \\
\text { the particular governments of the several States, } \\
\text { and instead thereof have established one general } \\
\text { government that is to pervade the union[.] }\end{array}$ \\
\hline
\end{tabular}




\begin{tabular}{|c|c|c|}
\hline Source & Record & Excerpt (emphasis added) \\
\hline $\begin{array}{l}2 \text { Complete Anti- } \\
\text { Federalist, supra } \\
\text { note } 32 \text {. }\end{array}$ & $\begin{array}{l}\text { 33. Federal Farmer } \\
\text { XVIII, The } \\
\text { Quantity of Power } \\
\text { the Union Must } \\
\text { Possess Is One } \\
\text { Thing; The Mode } \\
\text { of Exercising the } \\
\text { Powers Given Is } \\
\text { Quite A Different } \\
\text { Consideration, } \\
\text { January 23, 1788, } \\
\text { at } 349 .\end{array}$ & $\begin{array}{c}\text { The states all agreed about seven years ago [in the } \\
\text { Articles of Confederation], that the confederation } \\
\text { should remain unaltered, unless every state should } \\
\text { agree to alterations: but we now see it agreed } \\
\text { by the convention, and four states, that the old } \\
\text { confederacy shall be destroyed, and a new one ... } \\
\text { be erected[.] }\end{array}$ \\
\hline $\begin{array}{l}4 \text { Complete AnTi- } \\
\text { FEDERALIST, supra } \\
\text { note } 32 .\end{array}$ & $\begin{array}{l}\text { 34. A Farmer, (New } \\
\text { Hampshire), } \\
\text { Freeman's } \\
\text { Oracle and } \\
\text { New Hampshire } \\
\text { Advertiser, January } \\
\text { 11, 1788, at } 209 .\end{array}$ & $\begin{array}{l}\text { [Discussing whether states should approve the new } \\
\text { constitution, a Farmer said the following:] I think } \\
\text { the state of Virginia have ordered their convention } \\
\text { to object, amend, or make a new one as they } \\
\text { please. I wish every state would do the same, then a } \\
\text { continental convention would have a fair chance to } \\
\text { frame a constitution most agreeable to the general } \\
\text { sense of the people, and then let it be returned for } \\
\text { their approbation. [A Farmer thereby distinguished } \\
\text { between amending the new constitution and } \\
\text { making "a new one." Thus, it appears he did not } \\
\text { think an amendment to the new constitution could } \\
\text { be a complete substitute.] }\end{array}$ \\
\hline $\begin{array}{l}6 \text { Complete AnTi- } \\
\text { FEDERALIST, supra } \\
\text { note } 32 .\end{array}$ & \begin{tabular}{|l} 
35. \\
Address of the \\
Albany Antifederal \\
Committee, New \\
York Journal, April \\
26, 1788, at 122 .
\end{tabular} & $\begin{array}{l}\text { The [Philadelphia] convention, who were appointed } \\
\text { for the sole and express purpose of revising and } \\
\text { amending the [Articles of] confederation, have } \\
\text { taken upon themselves the power of making a } \\
\text { new one. They have not formed a federal but a } \\
\text { consolidated government[.] }\end{array}$ \\
\hline
\end{tabular}

